\title{
Review
}

\section{Serotonin and the neurobiology of the ejaculatory threshold}

\author{
Trynke R. de Jong, ${ }^{\mathrm{a}, \mathrm{b}, \mathrm{c}, *}$, Jan G. Veening ${ }^{\mathrm{a}, \mathrm{c}}$, Marcel D. Waldinger ${ }^{\mathrm{c}, \mathrm{d}}$, \\ Alexander R. Cools ${ }^{\mathrm{b}}$, Berend Olivier ${ }^{\mathrm{c}, \mathrm{e}}$ \\ ${ }^{a}$ Department of Anatomy, Radboud University Nijmegen Medical Centre, P.O. Box 9101, 6500 HB, Nijmegen, The Netherlands \\ ${ }^{\mathrm{b}}$ Department of Psychoneuropharmacology, Radboud University Nijmegen Medical Centre, P.O. Box 9101, 6500 HB, Nijmegen, The Netherlands \\ ${ }^{\mathrm{c}}$ Department of Psychopharmacology, Utrecht Institute of Pharmacological Sciences and Rudolf Magnus Institute of Neuroscience, Utrecht University, \\ P.O. Box 80082, 3508 TB, Utrecht, The Netherlands \\ ${ }^{\mathrm{d}}$ Department of Psychiatry, Leyenburg Hospital, P.O. Box 40551, 2504 LN, Den Haag, The Netherlands \\ ${ }^{\mathrm{e}}$ Department of Psychiatry, Yale University Medical School, 25 Park St., New Haven, CT 06519, USA
}

Received 5 August 2005; received in revised form 20 January 2006; accepted 25 January 2006

\begin{abstract}
Disorders of the ejaculatory threshold, such as lifelong premature ejaculation, are fairly common in humans and can have a great impact on the quality of life.

Research in humans and rats have indicated that increased serotonin levels in the central nervous system elevate the ejaculatory threshold, probably via 5- $\mathrm{HT}_{1 \mathrm{~B}}$ and $5-\mathrm{HT}_{2 \mathrm{C}}$ receptors, whereas depletion of serotonin decreases the ejaculatory threshold. 5 - $\mathrm{HT}_{1 \mathrm{~A}}$ receptor activation strongly lowers the ejaculatory threshold, probably mediated by both the reduction of serotonin levels via presynaptic $5-\mathrm{HT}_{1 \mathrm{~A}}$ receptors and yet unknown effects of postsynaptic $5-\mathrm{HT}_{1 \mathrm{~A}}$ receptors.

The present review attempts to integrate psychopharmacological data on serotonergic control over ejaculation with the knowledge of the neuroanatomical substrate of ejaculation, indicating the importance of the lumbosacral spinal cord, the nucleus paragigantocellularis, the lateral hypothalamic area and several other supraspinal areas. In addition, the gaps in our understanding of the role of serotonin in the ejaculatory threshold are discussed. Filling in those gaps might help to design specific drugs that alter the ejaculatory threshold, thereby alleviating ejaculatory disorders.
\end{abstract}

(C) 2006 Elsevier Ltd. All rights reserved.

Keywords: Ejaculation; 5-HT; SSRIs; Spinal cord; Nucleus paragigantocellularis; Lateral hypothalamic area

\section{Contents}

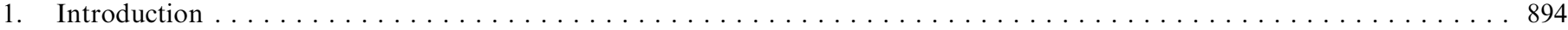

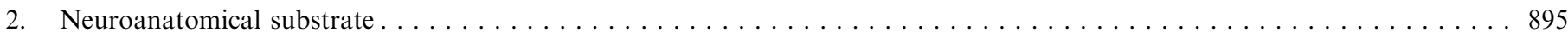

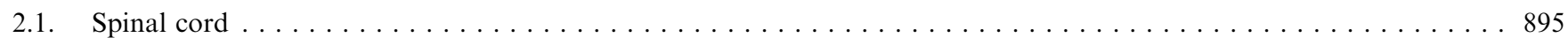

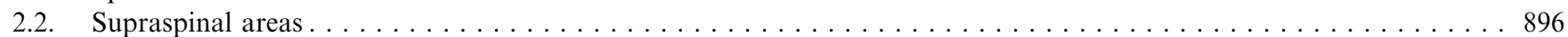

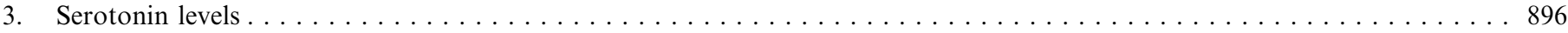

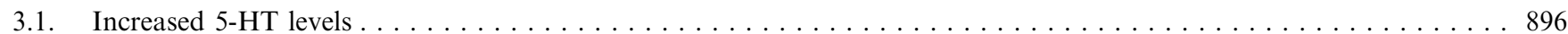

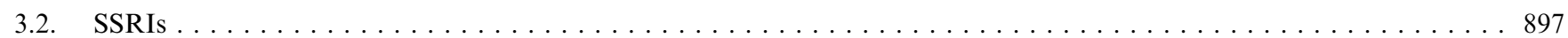

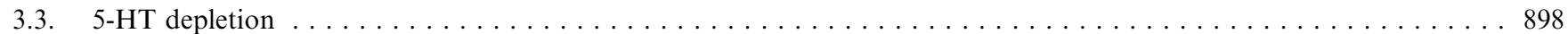

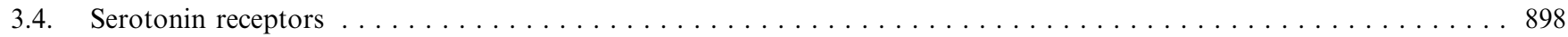

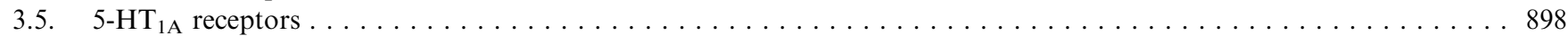

\footnotetext{
*Corresponding author. Faculty of Pharmaceutical Sciences, Department of Psychopharmacology, Room W. 124, University of Utrecht, Sorbonnelaan, 3584 CA Utrecht, Netherlands. Tel.: + 31302537383 ; fax: + 31302537387.
}

E-mail address: t.r.dejong@pharm.uu.nl (T.R. de Jong). 


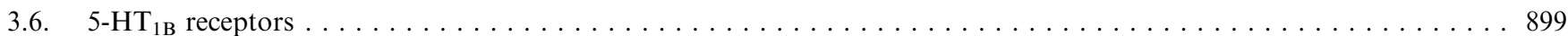

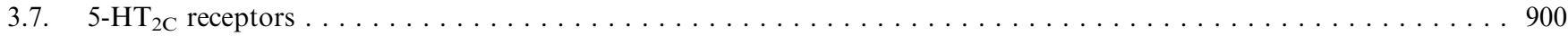

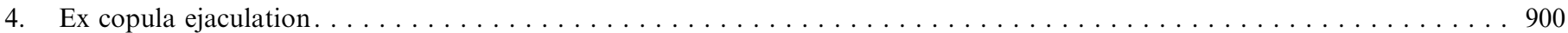

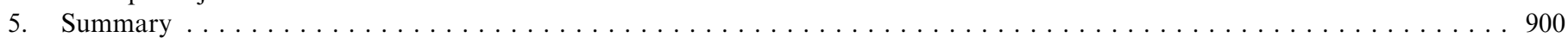

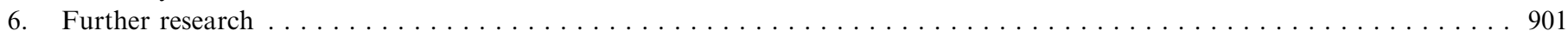

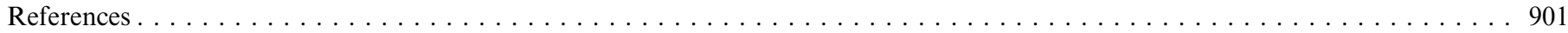

\section{Introduction}

Male sexual behaviour differs widely between mammalian species, but it has two common factors: the stimulation of the genitals by insertion of the penis into the vagina (intromission) and the expulsion of semen in the female genital tract (ejaculation) (Meisel and Sachs, 1994). The ejaculatory threshold, which can be defined as the number of intromissions preceding ejaculation (intromission frequency) and/or the latency time from the start of copulation to ejaculation (ejaculation latency), can therefore be determined for all male mammals including rats and humans (Bitran and Hull, 1987; Waldinger, 2003).

Investigating the ejaculatory threshold is of great importance, since disorders of this threshold, such as lifelong premature and retarded ejaculation, are fairly common in human males and can have a great impact on the quality of life (Hartmann and Waldinger, 2005; Waldinger, 2005; Waldinger and Schweitzer, 2005; Waldinger et al., 2005b). Premature ejaculation is now often successfully treated with antidepressant drugs that alter serotonergic neurotransmission (Waldinger, 2005), but drugs designed specifically to treat ejaculatory disorders are called for. In order to find such drugs, the neural substrate of the ejaculatory threshold needs to be determined, including all neuroanatomical, physiological and pharmacological aspects.

Although some research on ejaculation has been performed in men (Waldinger et al., 1998b, 2001), the practical and ethical limitations to conduct neuroanatomical and psychopharmacological experiments in humans require the use of animal models. The vast majority of sexual behaviour research has been performed in rats. Therefore, all experiments discussed in this review were conducted in rats unless stated otherwise. The reasons to use rats in sexual behaviour research are various (Pfaus,
1996), and include the fact that their intromissions and ejaculations are clearly discernable (Bitran and Hull, 1987). In addition, both rats and humans have an average ejaculation latency of about five minutes, although large individual differences exist within both human and rat populations (Olivier et al., 2005; Pattij et al., 2005; Waldinger et al., 2005a). Other aspects of sexual behaviour obviously differ between rat and human males. Rats are much more influenced by olfactory cues than humans, the male rat has little physical contact with the female in the seconds between each mount and intromission, and male rats have multiple ejaculations during copulation. A schematic overview of male rat sexual behaviour is given in Fig. 1, which is an adaptation of the figure in the review of Larsson and Ahlenius (Larsson and Ahlenius, 1999).

The neurotransmitter serotonin (5-HT) has been implicated in the central regulation of blood pressure, body fluid homeostasis, locomotion, food intake, nociception, cognition, arousal, stress responses, mood and many other autonomic and behavioural functions. The ubiquitous presence of 5-HT fibres throughout the central nervous system (Steinbusch, 1981), the many different 5-HT receptor subtypes (Barnes and Sharp, 1999), the variety of signal transduction mechanisms activated by each 5-HT receptor subtype (Raymond et al., 2001) and the diversity in autoregulatory mechanisms in the 5-HT system (Pineyro and Blier, 1999) make it highly complicated to unravel the precise role of serotonin in behaviour. The specific role of 5-HT in the ejaculatory threshold has been investigated since the early 1970s, and it was soon established that 5HT, in contrast to dopamine, inhibits ejaculation. Since then, increasingly sophisticated neuroanatomical and psychopharmacological tools have revealed more specific roles of 5-HT and its receptor subtypes in the ejaculatory threshold.

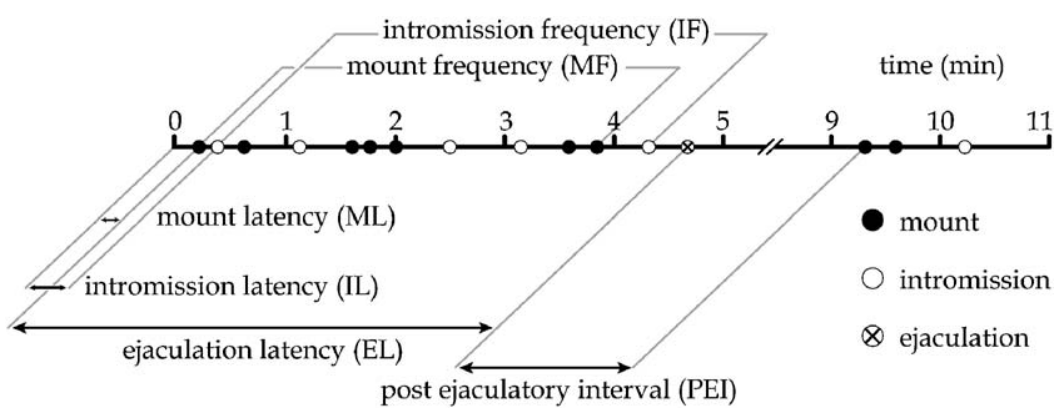

Fig. 1. The temporal pattern of male rat sexual behavior. Adapted from Larsson and Ahlenius (1999). 


\section{Neuroanatomical substrate}

The autonomic and somatic motor neurons that execute the different phases of ejaculation are located in the thoracolumbar and lumbosacral spinal cord. These motor neurons are activated in a coordinated manner when sufficient sensory input to reach the ejaculatory threshold has entered the central nervous system. Interneurons in the lumbar spinal cord as well as neurons originating from various supraspinal areas are thought to modulate the ejaculatory threshold, possibly using serotonin as neurotransmitter.

\subsection{Spinal cord}

Ejaculation occurs in two stages, referred to as emission and expulsion (ejection), which are executed via noradrenergic sympathetic, cholinergic parasympathetic and cholinergic somatic motor neurons originating in the spinal cord. Emission of spermatozoa from the testes and seminal fluids from the seminal vesicles and prostate is induced by sympathetic motor neurons in the thoracolumbar intermediolateral cell column (IML) and parasympathetic motor neurons in the sacral parasympathetic nucleus (SPN). Somatic motor neurons in the dorsolateral and dorsomedial ventral horn of the lumbosacral spinal cord cause rhythmic contractions of the striated ischiocavernosus and bulbospongiosus muscles in the pelvic floor that lead to the forceful expulsion of semen from the urethra (Coolen et al., 2004b; Marson and McKenna, 1996; McKenna, 2000; Steers, 2000; Waldinger et al., 1998a). A schematic overview of the relevant spinal cord areas is given in Fig. 2, which is an adaptation from the figures in Paxinos and Watson (Paxinos and Watson, 1998).

The motor neurons involved in ejaculation are triggered, amongst others, by sensory input from the genitals. This genitosensory input is predominantly generated by intromissions and reaches the dorsal horns and dorsal grey commissure of the lumbosacral spinal cord via the dorsal penile nerve, a branch of the pudendal nerve (McKenna and Nadelhaft, 1986; Ueyama et al., 1987). Urethral distension, which stimulates the dorsal penile nerve, elicits an 'urethrogenital reflex' in anesthetized rats with a transection of the spinal cord at the T6 level. This reflex includes rhythmic contractions of the striated muscles and expulsion of the urethral contents, and is therefore used as a model for ejaculation (Carro-Juarez and RodriguezManzo, 2000; Chung et al., 1988; Duran et al., 1997; McKenna et al., 1991).

Apparently, the relay of genitosensory input to ejaculatory motor output takes place at the level of the spinal cord in the form of a reflex arc. A group of galaninergic interneurons in the border area of laminae 7 and 10 at the lumbar 3 and 4 levels of the spinal cord, called the lumbar spinothalamic cells (LSt cells), is the most likely candidate for such a relay centre (Truitt and Coolen, 2002). Galaninergic fibres originating from the LSt cells project
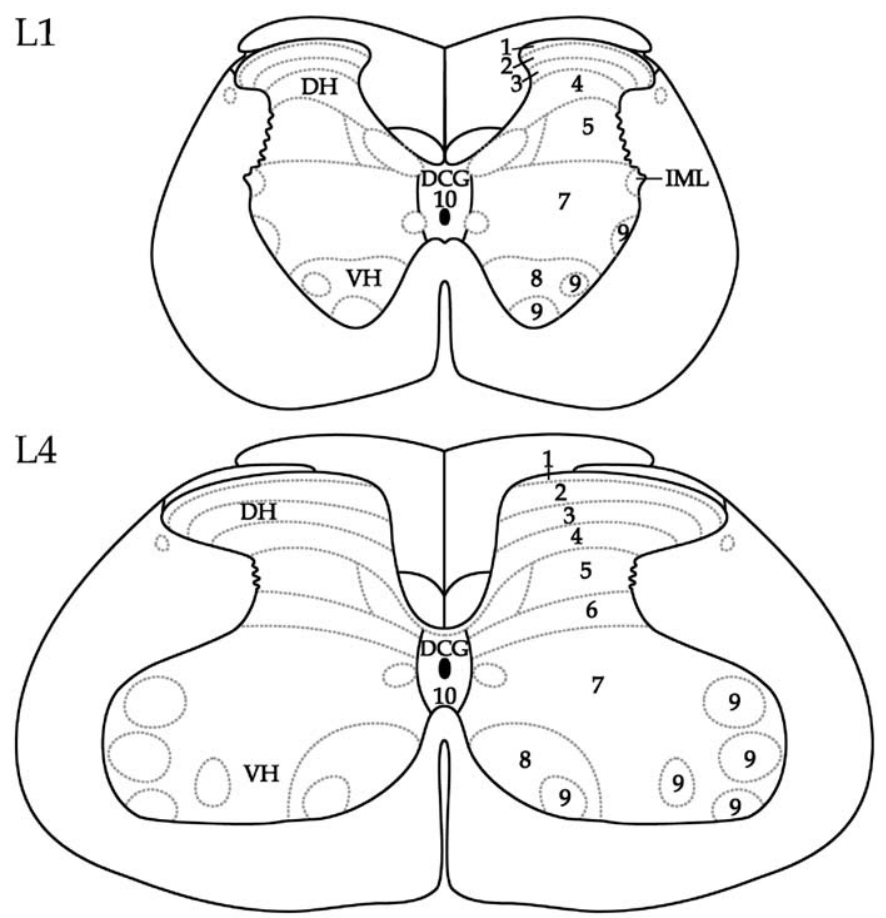

L6

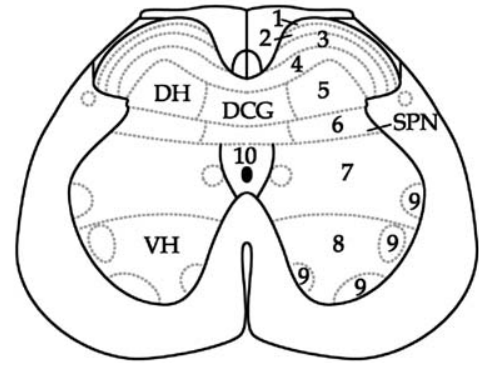

Fig. 2. Schematic representation of coronal spinal cord sections at the lumbar 1, 4 and 6 levels. Numbers represent the laminae; DH: dorsal horn; VH: ventral horn; DCG: dorsal commissural grey; IML: intermediate lateral cell column; SPN: sacral parasympathetic nucleus. Adapted from Paxinos and Watson (2005).

to all areas in the spinal cord containing motor neurons involved in ejaculation, and selective lesion of the LSt cells eliminates ejaculation without affecting other parameters of sexual behaviour (Truitt and Coolen, 2002; Xu et al., 2005). The activation of LSt cells probably plays an important role in the ejaculatory threshold.

Serotonergic fibres have been found in all the areas of the spinal cord containing sensory fibres and motor neurons involved in ejaculation, in particular the lumbosacral dorsal and ventral horns, dorsal commissural grey and IML and SPN (Maxwell et al., 1996; Ranson et al., 2003; Tang et al., 1998). Serotonergic fibres were found in close association with cell bodies in the IML showing Fosexpression in response to the urethrogenital reflex (Marson and Gravitt, 2004), and they make synaptic contact with SPN neurons labelled by retrograde tracers injected in the pelvic nerve as well as lumbosacral somatic motor neurons labelled by retrograde tracers injected in the striated pelvic floor muscles (Tang et al., 1998). In addition, serotonergic 
fibres have been found in close apposition to the LSt cells (Coolen et al., 2004a). Serotonin might affect ejaculation via any of these possible connections.

\subsection{Supraspinal areas}

A modulating role for supraspinal areas in the ejaculatory threshold was indicated by the finding that the urethrogenital reflex cannot be elicited in intact rats, but usually requires either thoracic spinal transection or lesion of the nucleus paragigantocellularis (nPGi), an area in the ventrolateral medulla in the brainstem (Marson and McKenna, 1990). Lesioning of the nPGi also facilitates ejaculation in copulating rats (Yells et al., 1992). Since neurons in the $\mathrm{nPGi}$ are consistently labelled when retrograde transneuronal tracers are injected into the penis, bulbospongiosus muscle, epididymis or prostate (Gerendai et al., 2001; Marson et al., 1993; Orr and Marson, 1998; Tang et al., 1999), the nPGi is thought to exert a tonic inhibition over ejaculation via relays in the spinal cord. Serotonin probably mediates this inhibition, since a large portion of neurons in the $\mathrm{nPGi}$ that project to the motor neurons innervating the bulbospongiosus muscle contain serotonin (Marson and McKenna, 1992). The medial preoptic area (MPOA), a hypothalamic brain area that integrates the sensory information induced by female pheromones and genital stimulation (Bressler and Baum, 1996; Coolen et al., 1998, 2003b) and is a crucial structure for the performance of sexual behaviour (Hansen et al., 1982; Liu et al., 1997b; Meisel and Sachs, 1994; Paredes et al., 1993), projects heavily to the nPGi via relays in the periaqueductal grey and might lower the ejaculatory threshold by removing the tonic serotonergic inhibition exerted by the nPGi (Marson, 2004; Marson and McKenna, 1994b; Murphy and Hoffman, 2001; Murphy et al., 1999). Stimulation of the MPOA can elicit the urethrogenital reflex, even without spinal transection or lesion of the nPGi (Marson and McKenna, 1994b).

Besides the MPOA-PAG-nPGi-spinal cord pathway, there is at least one other serotonergic pathway that influences sexual behaviour. Serotonin release in the anterior lateral hypothalamic area, most likely from axons originating from the dorsal and median raphe nuclei and travelling through the medial forebrain bundle (van de Kar and Lorens, 1979), increases sharply in response to an ejaculation (Lorrain et al., 1997). This is thought to induce the suppression of copulation during the post-ejaculatory interval, and could be partly mediated by an inhibition of dopaminergic neurotransmission in the nucleus accumbens (Lorrain et al., 1999). Indeed, electrolytic lesions of the median raphe nucleus and, less consistently, the dorsal raphe nucleus lowered the ejaculatory threshold by reducing intromission frequency and ejaculation latency (Albinsson et al., 1996; McIntosh and Barfield, 1984). Selective degeneration of serotonergic fibres in the medial forebrain bundle by local injection of the serotonergic toxin 5,7-dihydroxytryptamine (5,7-DHT) led to an in- creased percentage of rats ejaculating and a decreased intromission frequency compared to sham-lesioned rats (Rodriguez et al., 1984).

In these two pathways, the link between serotonergic neurotransmission and ejaculation is evident. In many other brain areas that are known to influence ejaculation, a mediating role of serotonin is possible but not yet demonstrated. Experiments using lesions (Kondo and Yamanouchi, 1995; Liu et al., 1997b) or the staining of Fos (Baum and Everitt, 1992; Coolen et al., 1997a, 1996; Greco et al., 1996) in rats, gerbils and hamsters have implicated the medial amygdala, the posterior medial bed nucleus of the stria terminalis and the medial parvocellular subparafascicular thalamic nucleus in ejaculation and the post-ejaculatory interval, possibly via their reciprocal connections with the MPOA (Coolen et al., 1998, 2003a; Heeb and Yahr, 2001; Parfitt and Newman, 1998). These areas contain some serotonergic fibres (Steinbusch, 1981) that might play a role in the effects on ejaculation.

Furthermore, the nucleus accumbens, paraventricular hypothalamic nucleus and arcuate hypothalamic nucleus all receive serotonergic input (Casu et al., 2004; Larsen et al., 1996; Steinbusch, 1981; Steinbusch and Nieuwenhuys, 1981). The nucleus accumbens is thought to play a role in sexual motivation and reward (Balfour et al., 2004), and lesion of this nucleus disrupts ejaculation (Kippin et al., 2004). The paraventricular hypothalamic nucleus contains oxytocin that lowers the ejaculatory threshold (Stoneham et al., 1985), and lesion of this nucleus increases the ejaculatory threshold (Liu et al., 1997a). The arcuate hypothalamic nucleus is connected with the MPOA, the medial amygdala, the bed nucleus of the stria terminalis and the paraventricular nucleus, and is thought to integrate information about metabolism with reproductive activity (Gottsch et al., 2004; Magoul et al., 1994). In conclusion, the current understanding of the neuroanatomical association between serotonin and the ejaculatory threshold is far from complete and needs to be further investigated.

\section{Serotonin levels}

In the last four decades, many researchers have demonstrated that pharmacological manipulations of serotonergic neurotransmission markedly changed parameters of sexual behaviour, in particular the intromission frequency and ejaculation latency.

\subsection{Increased 5-HT levels}

Since 5-HT does not cross the blood brain barrier, the net effects of serotonin on the ejaculatory threshold have been investigated using systemic injection of the 5-HT precursor 5-hydroxytryptophan (5-HTP), which does cross the blood brain barrier. 5-HTP has been found to increase 5-HT release from serotonergic neurons in the lateral hypothalamic area and the lumbar spinal cord for as long as three hours (Gartside et al., 1992; Kimura et al., 1983; 
Samathanam et al., 1989; Shimizu et al., 1992). Systemic injection of 5-HTP increased the intromission frequency and ejaculation latency in rats (Ahlenius and Larsson, 1984, 1985, 1991, 1998; Ahlenius et al., 1980; FernandezGuasti and Rodriguez-Manzo, 1992), and mongrel dogs treated with 5-HTP failed to ejaculate upon genital stimulation (Kimura et al., 1977). Serotonin levels can also be elevated throughout the central nervous system by acute systemic administration of the 5-HT releasers parachloroamphetamine ( $p$-CA) or fenfluramine (Gardier et al., 1994; Schwartz et al., 1989; Series et al., 1994). This leads to an increased ejaculation latency as well (Foreman et al., 1992).

To avoid the blood brain barrier, 5-HT can be injected directly into the brain or the cerebrospinal fluid. Local injection of 5-HT into the nucleus accumbens, MPOA and amygdala, as well as intracerebroventricular or intrathecal injections, increased the intromission frequency and ejaculation latency (Drago et al., 1999; Fernandez-Guasti et al., 1992b; Hillegaart et al., 1991) or decreased the percentage of rats that reached an ejaculation (Svensson and Hansen, 1984; Verma et al., 1989). Thus, the elevation of serotonin levels in many brain areas and the spinal cord increases the ejaculatory threshold.

Conversely, local injection of 5-HT in low doses into the dorsal or median raphe nuclei lowered the ejaculatory threshold (Hillegaart et al., 1989), interpreted by assuming that feedback systems, which inhibit cell firing and decrease 5-HT levels in projection areas, were activated (Pineyro and Blier, 1999). However, injection of higher doses of 5-HT into the dorsal and median raphe nuclei had no effect on ejaculation (Fernandez-Guasti et al., 1992a; Hillegaart et al., 1989).

\subsection{SSRIS}

The selective serotonin reuptake inhibitors (SSRIs) fluoxetine, paroxetine, fluvoxamine, citalopram and sertraline are widely used and effective antidepressants. They all act similarly by blocking 5-HT transporters, thereby preventing the reuptake of 5-HT from the synaptic cleft into the presynaptic serotonergic neuron. This leads to elevated extracellular 5-HT levels, as shown by microdialysis studies following acute systemic administration of fluoxetine (Bymaster et al., 2002; Felton et al., 2003; Hervas and Artigas, 1998; Malagie et al., 1995), paroxetine (Hajos-Korcsok et al., 2000; Malagie et al., 2000; Nakayama, 2002), fluvoxamine (Ago et al., 2005; Bosker et al., 1995; Denys et al., 2004), citalopram (Invernizzi et al., 1995; Moret and Briley, 1996; Wegener et al., 2003; Yoshitake et al., 2003) and sertraline (Sprouse et al., 1996; Zhang et al., 2000).

Besides an increased activation of postsynaptic 5-HT receptors, elevated 5-HT levels also turn on negative feedback systems via serotonin autoreceptors, leading to a reduced release of serotonin from nerve terminals. This probably attenuates acute effects of SSRI treatment on mood disorders. During chronic SSRI-treatment (3-4 weeks) 5-HT autoreceptors, especially 5 - $\mathrm{HT}_{1 \mathrm{~A}}$ receptors, become desensitized, and this has been proposed as one means to enable the antidepressant effects to occur (Blier et al., 1998; Elena Castro et al., 2003; Hensler, 2003; Invernizzi et al., 1996; Le Poul et al., 2000; Newman et al., 2004; Pineyro and Blier, 1999).

Treatment with SSRIs often causes sexual problems, of which delayed ejaculation and the inability to ejaculate are the most commonly reported (Gregorian et al., 2002; Montgomery et al., 2002; Rosen et al., 1999). These side effects are generally perceived as negative, but SSRIinduced delayed ejaculation has turned out to be very useful in the treatment of lifelong premature ejaculation (Chia, 2002; Kara et al., 1996; Kim and Seo, 1998; McMahon et al., 2004; Moreland and Makela, 2005; Waldinger et al., 2004).

The use of the so-called intravaginal ejaculation latency time (IELT), as measured with a stopwatch (Waldinger, 2003), has greatly increased the amount of objective data on the effects of SSRIs on the ejaculatory threshold. Interestingly, this method revealed marked differences between SSRIs in their ability to delay ejaculation in patients suffering from premature ejaculation: paroxetine delayed ejaculation more strongly than the other SSRIs, whereas citalopram and fluvoxamine affected ejaculation much less (Waldinger et al., 1998b, 2001, 2004). In addition, the effects of paroxetine and fluoxetine became clinically relevant only after a few weeks of chronic treatment and increased over time (Waldinger et al., 1998b, 2001).

There have been some studies dealing with the effects of SSRIs on sexual behaviour in rats. These studies often failed to find a significant effect of acute systemic injection of several SSRIs on the ejaculatory threshold (Ahlenius et al., 1979; Ahlenius and Larsson, 1999; Cantor et al., 1999; de Jong et al., 2005a, b; Mos et al., 1999), although acutely administered fluoxetine or paroxetine sometimes delayed ejaculation (Waldinger et al., 2002; Yells et al., 1994), and acute local injection of the SSRI alaproclate into the lateral hypothalamic area increased both local serotonin levels and ejaculation latency (Lorrain et al., 1997). Apparently, the ejaculatory threshold is somewhat less sensitive to acute systemic injection of an SSRI compared to acute systemic injection of 5-HTP, despite their shared ability to elevate serotonin levels. This might be explained by the difference in pharmacology between the two drugs: 5-HTP increases 5-HT release, whereas SSRIs prevent 5-HT reuptake. However, a direct comparison between the two compounds on 5-HT levels in brain areas relevant for ejaculation has not yet been performed.

Delayed ejaculation reliably occurs in rats in response to chronic treatment with paroxetine or fluoxetine (de Jong et al., 2005b; Vega et al., 1998; Waldinger et al., 2002), but less so or not at all in response to citalopram or fluvoxamine (de Jong et al., 2005a, b; Waldinger et al., 2002), which resembles the situation in humans (Waldinger 
et al., 1998b, 2001). The difference between acute and chronic treatment suggests that desensitization mechanisms may play a role in the effects of paroxetine and fluoxetine on ejaculation. In addition, the lack of effects of fluvoxamine and citalopram indicate that these desensitization mechanisms vary from one SSRI to another. More evidence in that direction is discussed in the paragraph about $5-\mathrm{HT}_{1 \mathrm{~A}}$ receptors.

\subsection{5-HT depletion}

Multiple systemic injections of para-chlorophenylalanine (p-CPA), which strongly depletes 5-HT in the central nervous system (Kimura et al., 1977; Qureshi et al., 1989), decreased the ejaculation latency (Ahlenius et al., 1971; Dahlof and Larsson, 1979; Gessa and Tagliamonte, 1974; Qureshi et al., 1989; Salis and Dewsbury, 1971; Yamanouchi and Kakeyama, 1992) and intromission frequency (Fernandez-Guasti and Escalante, 1991) and increased the ejaculation frequency (Tsutsui et al., 1994; Yamanouchi and Kakeyama, 1992). Intracerebroventricular injection of 5,7-DHT, which decreased serotonin levels in the hypothalamus, brainstem and spinal cord, enabled the urethrogenital reflex to occur upon urethral distension in intact rats. A similar result was found when 5,7-DHT was injected intrathecally, which decreased serotonin levels only in the spinal cord (Marson and McKenna, 1994a). Taken together, a decrease in serotonin levels in the spinal cord and supraspinal areas lowers the ejaculatory threshold.

\subsection{Serotonin receptors}

The abundant evidence that serotonin is involved in the mechanisms mediating the ejaculatory threshold encouraged researchers to determine which serotonin receptors contribute to this process. The increasing availability of selective serotonin receptor agonists and antagonists greatly advanced the knowledge about the roles of specific receptor subtypes. So far, $5-\mathrm{HT}_{1 \mathrm{~A}}, 5-\mathrm{HT}_{1 \mathrm{~B}}$ and $5-\mathrm{HT}_{2 \mathrm{C}}$ receptors are the only serotonin receptor subtypes that have been shown to affect the ejaculatory threshold. All three receptor subtypes are located in the thoracolumbar IML, the lumbar dorsal commissural grey and laminae 7 and 10, the lumbosacral dorsal and ventral horns and the SPN (Bancila et al., 1999; Fonseca et al., 2001; Thor et al., 1993), indicating that serotonin may modulate the ejaculatory threshold directly via these receptors in the spinal cord. In addition, the presence of these 5-HT receptor subtypes in supraspinal areas involved in ejaculation may play a role as well.

\section{5. $5-H T_{1 A}$ receptors}

5- $\mathrm{HT}_{1 \mathrm{~A}}$ receptors are positioned presynaptically on the soma and dendrites of serotonergic neurons as well as postsynaptically on neurons containing a wide variety of neurotransmitters (Barnes and Sharp, 1999). Activation of somatodendritic 5- $\mathrm{HT}_{1 \mathrm{~A}}$ autoreceptors leads to a potent inhibition of the firing frequency of serotonergic neurons (Hajos et al., 1999), constituting a negative feedback system through inhibition of 5-HT release in projection areas (Hjorth and Sharp, 1991; Pineyro and Blier, 1999). Activation of postsynaptic $5-\mathrm{HT}_{1 \mathrm{~A}}$ heteroreceptors can lead to a wide variety of actions, depending on the electrophysiological properties, projection areas and neurotransmitters used by the postsynaptic neuron.

The staining of $5-\mathrm{HT}_{1 \mathrm{~A}}$ receptor proteins or $\mathrm{mRNA}$ has shown that these receptors are located in the raphe nuclei (Kia et al., 1996; Li et al., 1997a; Pompeiano et al., 1992; Wright et al., 1995) and the nucleus paragigantocellularis (Helke et al., 1997; Kia et al., 1996; Pompeiano et al., 1992), where they probably act as autoreceptors on serotonergic neurons. Postsynaptic $5-\mathrm{HT}_{1 \mathrm{~A}}$ receptors are distributed throughout the brain, including nuclei implicated in ejaculation such as the MPOA (Aznar et al., 2003; Pompeiano et al., 1992), lateral hypothalamic area (Collin et al., 2002; Kia et al., 1996; Li et al., 1997a), medial amygdala (Aznar et al., 2003; Li et al., 1997a; Pompeiano et al., 1992), bed nucleus of the stria terminalis (Kia et al., 1996; Pompeiano et al., 1992), nucleus accumbens (Aznar et al., 2003; Wright et al., 1995), paraventricular hypothalamic nucleus (Collin et al., 2002; Li et al., 1997a; Zhang et al., 2004) and arcuate hypothalamic nucleus (Aznar et al., 2003; Collin et al., 2002).

Selective activation of $5-\mathrm{HT}_{1 \mathrm{~A}}$ receptors has a remarkably strong effect on the ejaculatory threshold. The first report that systemic administration of the $5-\mathrm{HT}_{1 \mathrm{~A}}$ receptor agonist 8-OH-DPAT reduced the intromission frequency and ejaculation latency was published in 1981 (Ahlenius et al., 1981), and this finding has been reproduced many times (Ahlenius and Larsson, 1984; Coolen et al., 1997b; Fernandez-Guasti and Rodriguez-Manzo, 1997; Mendelson and Gorzalka, 1986; Morali and Larsson, 1984; Rehman et al., 1999; Schnur et al., 1989; Sura et al., 2001). Although 8-OH-DPAT has considerable affinity for the 5-HT7 receptor (Bard et al., 1993; Neumaier et al., 2001), the findings that systemic injection of other $5-\mathrm{HT}_{1 \mathrm{~A}}$ receptor agonists had similar effects on ejaculation (Ahlenius and Larsson, 1991; Andersson and Larsson, 1994; Haensel and Slob, 1997; Mathes et al., 1990) and that these effects could be reversed completely by systemic injection of selective 5- $\mathrm{HT}_{1 \mathrm{~A}}$ receptor antagonists (Ahlenius and Larsson, 1998; Hillegaart and Ahlenius, 1998) indicate that $5-\mathrm{HT}_{1 \mathrm{~A}}$ receptor activation is responsible for the lowering of the ejaculatory threshold.

The somewhat puzzling opposite effects of 5-HT itself, which is the natural ligand of $5-\mathrm{HT}_{1 \mathrm{~A}}$ receptors, versus $5-\mathrm{HT}_{1 \mathrm{~A}}$ receptor agonists on the ejaculatory threshold might be explained by their activation of somatodendritic $5-\mathrm{HT}_{1 \mathrm{~A}}$ autoreceptors, which causes a reduction of 5-HT levels in projection areas and thus mimics the effects of serotonin depletion (Hjorth and Sharp, 1991; Hughes et al., 2005; Invernizzi et al., 1995, 1996). Indeed, micro-injection of 8-OH-DPAT into the median raphe nucleus reduced the 
ejaculation latency and intromission frequency (Hillegaart et al., 1991), although a similar injection into the dorsal raphe nucleus failed to affect sexual behaviour (FernandezGuasti et al., 1992b; Hillegaart et al., 1991).

On the other hand, the reduction of intromission frequency and ejaculation latency following depletion of 5-HT levels by systemic injection of $p$-CPA or intracerebroventricular injection of 5,7 DHT was further decreased by systemic administration of 8-OH-DPAT (FernandezGuasti and Escalante, 1991), suggesting that both pre- and postsynaptic $5-\mathrm{HT}_{1 \mathrm{~A}}$ receptors are involved in the lowering of the ejaculatory threshold. In addition, intrathecal injection of $5-\mathrm{HT}_{1 \mathrm{~A}}$ receptor agonists strongly reduced the intromission frequency and ejaculation latency (Lee et al., 1990; Mathes et al., 1990; Svensson and Hansen, 1984). Since the spinal cord contains neither serotonergic cell bodies nor $5-\mathrm{HT}_{1 \mathrm{~A}}$ autoreceptors, spinal postsynaptic $5-\mathrm{HT}_{1 \mathrm{~A}}$ receptors probably mediated these effects. Moreover, micro-injection of $5-\mathrm{HT}_{1 \mathrm{~A}}$ receptor agonists in the nucleus accumbens and MPOA lowered the ejaculatory threshold as well (Fernandez-Guasti et al., 1992b; Hillegaart et al., 1991; Matuszewich et al., 1999), suggesting an additional role for supraspinal $5-\mathrm{HT}_{1 \mathrm{~A}}$ receptors. However, the ability of 8-OH-DPAT to increase dopamine levels (Gobert et al., 1998) and bind to D2 receptors (Rinken et al., 1999) might mediate some of the effects on ejaculation in these areas. Indeed, local injection of 8-OHDPAT in the MPOA led to increased dopamine levels in that area (Lorrain et al., 1998) and a lowering of the ejaculatory threshold that could be reversed by a D2 receptor antagonist, but not a $5-\mathrm{HT}_{1 \mathrm{~A}}$ receptor antagonist (Matuszewich et al., 1999). It should be noted here that, in contrast to systemic injection, local injection with 8-OHDPAT increased serotonin levels in the MPOA (Lorrain et al., 1998). This finding indicates that elevated serotonin levels in the MPOA do not always coincide with an increased ejaculatory threshold. Possibly, the simultaneously elevated dopamine levels and increased D2 receptor activation acted as compensatory mechanisms in this particular situation.

The effects of 5-HT $\mathrm{HA}_{1 \mathrm{~A}}$ receptor agonists on the ejaculatory threshold are not universal. Systemic injection of $8-\mathrm{OH}-$ DPAT inhibits ejaculation in mice (Rodriguez-Manzo et al., 2002), rabbits (Paredes et al., 2000), dogs (Yonezawa et al., 2004) and ferrets (Paredes et al., 1994), and either lowers or elevates the ejaculatory threshold in rhesus monkeys, depending on dose (Pomerantz et al., 1993b). Since 5-HT $1 \mathrm{~A}$ autoreceptors probably have the same location and function in different mammalian species (Price et al., 1996), a difference in distribution of postsynaptic $5-\mathrm{HT}_{1 \mathrm{~A}}$ receptors in brain and spinal cord areas might explain this $8-\mathrm{OH}-$ DPAT induced elevation of the ejaculatory threshold.

Interestingly, systemic injection of the selective $5-\mathrm{HT}_{1 \mathrm{~A}}$ receptor antagonist WAY-100635 does not increase the ejaculatory threshold by itself, indicating that activation of $5-\mathrm{HT}_{1 \mathrm{~A}}$ receptors is not necessary to reach ejaculation during normal copulation (Ahlenius and Larsson, 1998; de
Jong et al., 2005a). However, WAY-100635 strongly enhances the increased ejaculatory threshold induced by 5-HTP (Ahlenius and Larsson, 1998) or acute SSRItreatment (Ahlenius and Larsson, 1999; de Jong et al., 2005a; Looney et al., 2005). This could be mediated by the blockade of 5-HT $1 \mathrm{~A}$ autoreceptors that normally limit the increase in 5-HT levels induced by 5-HTP or SSRIs, or blockade of postsynaptic 5- $\mathrm{HT}_{1 \mathrm{~A}}$ receptors that lower the ejaculatory threshold via the activation, disinhibition or perhaps inhibition of neurons in brain and spinal cord areas involved in ejaculation.

These findings imply that $5-\mathrm{HT}_{1 \mathrm{~A}}$ receptor activation becomes increasingly important to reach the ejaculatory threshold when serotonin levels are elevated, and that a combination of elevated serotonin levels and impaired $5-\mathrm{HT}_{1 \mathrm{~A}}$ receptor functioning strongly inhibits ejaculation. This might underlie SSRI-induced delayed ejaculation, since chronic treatment with the SSRI paroxetine, which delays ejaculation, reduced the facilitation of ejaculation induced by 8-OH-DPAT in rats (de Jong et al., 2005b), probably through $5-\mathrm{HT}_{1 \mathrm{~A}}$ receptor desensitization (Le Poul et al., 1995; Li et al., 1997b). Chronic treatment with fluvoxamine, an SSRI that has no sexual side effects in humans, failed to delay ejaculation and to reduce the effects of 8-OH-DPAT on ejaculation in rats (de Jong et al., 2005b). Further research might elucidate whether desensitization of pre- or postsynaptic $5-\mathrm{HT}_{1 \mathrm{~A}}$ receptors plays a role in SSRI-induced delayed ejaculation.

\section{6. $5-H T_{1 B}$ receptors}

5- $\mathrm{HT}_{1 \mathrm{~B}}$ receptors are located on pre- and postsynaptic axon terminals, where they act as autoreceptors and inhibit serotonin release (Barnes and Sharp, 1999; Raymond et al., 2001; Sari, 2004) or as heteroreceptors by inhibiting the release of various neurotransmitters (Clark and Neumaier, 2001; Sari, 2004). 5-HT ${ }_{1 \mathrm{~B}}$ receptors are found in the raphe nuclei, lateral hypothalamic area, bed nucleus of the stria terminalis, nucleus accumbens, paraventricular hypothalamic nucleus and arcuate hypothalamic area (Makarenko et al., 2002; Neumaier et al., 1996).

Systemic injection of the selective $5-\mathrm{HT}_{1 \mathrm{~B}}$ receptor agonist anpirtoline elevated the ejaculatory threshold by increasing the ejaculation latency and intromission frequency, which could be reversed by several $5-\mathrm{HT}_{1 \mathrm{~B}}$ receptor antagonists (Hillegaart and Ahlenius, 1998). In addition, systemic injection of the mixed $5-\mathrm{HT}_{1 \mathrm{~B}} / 2 \mathrm{C}$ receptor agonist $N$-[3-(trifluoromethyl)phenyl] piperazine (TFMPP) strongly reduced the percentage of rats ejaculating (Fernandez-Guasti et al., 1989), and local injection of TFMPP in the nucleus accumbens or MPOA increased the ejaculation latency (Fernandez-Guasti et al., 1992b). However, since 5- $\mathrm{HT}_{1 \mathrm{~B}}$ receptors have not been found in the MPOA, these effects might have been mediated partly by $5-\mathrm{HT}_{2 \mathrm{C}}$ receptors.

The elevation of the ejaculatory threshold by systemic injection of 5-HTP could be reversed by the $5-\mathrm{HT}_{1 \mathrm{~B}}$ 
receptor antagonist isamoltane (Ahlenius and Larsson, 1998), indicating that $5-\mathrm{HT}_{1 \mathrm{~B}}$ receptors mediate the inhibition of ejaculation induced by serotonin. However, systemic injection of $5-\mathrm{HT}_{1 \mathrm{~B}}$ receptor antagonists did not affect or very weakly facilitated ejaculation (Ahlenius and Larsson, 1998; Hillegaart and Ahlenius, 1998), indicating that during normal copulation the ejaculatory threshold is not maintained solely by $5-\mathrm{HT}_{1 \mathrm{~B}}$ receptor activation. In addition, the ejaculatory threshold is increased in $5-\mathrm{HT}_{1 \mathrm{~B}}$ knockout mice compared to wild type mice, indicating that the absence of $5-\mathrm{HT}_{1 \mathrm{~B}}$ receptors does not facilitate ejaculation in mice.

Possible mechanisms by which $5-\mathrm{HT}_{1 \mathrm{~B}}$ receptors inhibit ejaculation have not yet been demonstrated. A role of $5-\mathrm{HT}_{1 \mathrm{~B}}$ autoreceptors seems unlikely, since these receptors cause a reduction of serotonin release that would be expected to lower the ejaculatory threshold. 5- $\mathrm{HT}_{1 \mathrm{~B}}$ heteroreceptor activation possibly inhibits the release of neurotransmitters that facilitate ejaculation, such as acetylcholine (Duran et al., 2000; Sarhan and Fillion, 1999), glutamate (Chambille and Rampin, 2002; Powell et al., 2003; Sari, 2004) or perhaps galanin (Coolen et al., 2004a), in brain and spinal cord areas involved in the ejaculatory threshold.

\section{7. $5-H T_{2 C}$ receptors}

5- $\mathrm{HT}_{2 \mathrm{C}}$ receptors are found on postsynaptic dendrites where they generally cause cell excitation. They have not been implicated in autoregulatory feedback mechanisms (Barnes and Sharp, 1999). 5- $\mathrm{HT}_{2 \mathrm{C}}$ receptors are widely distributed in the central nervous system, including the raphe nuclei, MPOA, medial amygdala, bed nucleus of the stria terminalis, nucleus accumbens and arcuate hypothalamic nucleus (Abramowski et al., 1995; Clemett et al., 2000).

Systemic injection of the non-selective $5-\mathrm{HT}_{2}$ receptor agonist $[+/-]-2,5$-dimethoxy-4-iodoamphetamine (DOI) strongly decreased the percentage of rats ejaculating and increased the ejaculation latency, which could be reversed by several 5-HT2 receptor antagonists (Foreman et al., 1989; Klint et al., 1992; Klint and Larsson, 1995; Watson and Gorzalka, 1991). Systemic administration of the 5- $\mathrm{HT}_{2 \mathrm{C}}$ agonist $\mathrm{m}-\mathrm{CPP}$ produced a dose-dependent decline in the percent of rats and male rhesus monkeys achieving ejaculation (Mendelson and Gorzalka, 1990; Pomerantz et al., 1993a).

The elevation of the ejaculatory threshold induced by systemic injection of the serotonin-releasers $p$-CA and fenfluramine could be prevented by pre-treatment with the 5-HT 2 receptor antagonist LY53857 (Foreman et al., 1992), whereas the increased ejaculation latency induced by 5 -HTP could not be reversed by the $5-\mathrm{HT}_{2}$ receptor antagonist ritanserin (Ahlenius and Larsson, 1998). Systemic injection of the 5-HT2 receptor antagonist LY53857 reduced the ejaculation latency (Foreman et al., 1989), whereas ritanserin had no such effect (Watson and
Gorzalka, 1991). Possibly, yet unknown differences in the neuropharmacological properties of these antagonists could explain the differences in their effect on the ejaculatory threshold.

So far, there are no reports on the possible mechanisms by which $5-\mathrm{HT}_{2 \mathrm{C}}$ receptor activation elevates the ejaculatory threshold. The presence of $5-\mathrm{HT}_{2 \mathrm{C}}$ receptors in many spinal and supraspinal areas involved in ejaculation indicates numerous options that should be investigated extensively.

\section{Ex copula ejaculation}

Some studies on the effect of 5-HT on the ejaculatory threshold used the occurrence of spontaneous, ex copula ejaculations as a model. These seminal emissions are not dependent on genital stimulation and can be evoked by the injection of the 5-HT releaser p-CA (Humphries et al., 1981; Renyi, 1985; Yonezawa et al., 2000) or the nonselective 5-HT receptor agonist Me-ODMT (Mas et al., 1985), which respectively increase (Foreman et al., 1992) or decrease (Ahlenius and Larsson, 1991; Fernandez-Guasti et al., 1986) the ejaculatory threshold during copulation. Serotonin depletion induced by $p$-CPA, which by itself did not affect spontaneous ejaculation (Humphries et al., 1981), prevented the ex copula ejaculations caused by $p$-CA (Renyi, 1985; Yonezawa et al., 2000). The effects of $p$-CA and 5-MeODMT on spontaneous ejaculation could not be reversed by thoracic spinal transection (Mas et al., 1985; Yonezawa et al., 2000). These results suggest that activation of spinal serotonin receptors can directly activate the motor neurons involved in seminal emission. $5-\mathrm{HT}_{1 \mathrm{~A}}$ receptors seem likely candidates, but both systemic and intrathecal injection of 8-OH-DPAT (Lee et al., 1990; Rehman et al., 1999; Schnur et al., 1989) and buspirone (Mathes et al., 1990; Rehman et al., 1999), which strongly decrease the ejaculatory threshold in copula, inhibited spontaneous ex copula ejaculations. Although intracerebroventricular injection of 8-OH-DPAT induced rythmic contractions of the bulbospongiosus muscle, which is one aspect of ejaculation, this effect was probably mediated by D2 receptors (Clement et al., 2005). Taken together, these data indicate that the occurrence of spontaneous ex copula ejaculations is not representative of the situation during copulation, and should be used with great care as a model for the ejaculatory threshold.

\section{Summary}

Neuroanatomical studies have shown that there are at least two serotonergic pathways involved in the ejaculatory threshold. The tonic release of serotonin in the lumbosacral spinal cord originating from neurons in the $\mathrm{nPGi}$ inhibits ejaculation until sensory input overrules this tonic inhibition. Serotonin release in response to ejaculation in the anterior lateral hypothalamic area, and perhaps the medial amygdala and medial bed nucleus of the stria terminalis, 
mediates the inhibition of copulation during the postejaculatory interval.

Psychopharmacological experiments revealed that injection of drugs that increase 5-HT levels in the central nervous system, including the lumbosacral spinal cord, lateral hypothalamic area, MPOA, amygdala and nucleus accumbens, elevates the ejaculatory threshold. $5-\mathrm{HT}_{1 \mathrm{~B}}$ and $5-\mathrm{HT}_{2 \mathrm{C}}$ receptors possibly mediate this, because activation of these receptors inhibits ejaculation whereas their blockade prevents the inhibition of ejaculation by elevated serotonin levels.

Depletion of 5-HT in the central nervous system decreases the ejaculatory threshold. This might occur naturally during copulation, when pheromonal and genital stimulation are thought to trigger the MPOA to inhibit the serotonergic cell firing in the $\mathrm{nPGi}$, which reduces serotonin release in the lumbosacral spinal cord. Reduced activation of inhibitory postsynaptic 5- $\mathrm{HT}_{1 \mathrm{~B}}$ and/or $5-\mathrm{HT}_{2 \mathrm{C}}$ receptors in the lumbosacral spinal cord might be responsible for the facilitation of ejaculation following 5 -HT depletion, although systemic injection of $5-\mathrm{HT}_{1 \mathrm{~B}}$ or 5- $\mathrm{HT}_{2 \mathrm{C}}$ receptor antagonists alone do not consistently lower the ejaculatory threshold.

The role of 5- $\mathrm{HT}_{1 \mathrm{~A}}$ receptors in the ejaculatory threshold is somewhat more complicated. Activation of 5-HT $1 \mathrm{~A}$ receptors strongly lowers the ejaculatory threshold, and this is thought to be mediated by both reduction of 5-HT levels via $5-\mathrm{HT}_{1 \mathrm{~A}}$ autoreceptors and yet unknown effects of spinal or supraspinal postsynaptic $5-\mathrm{HT}_{1 \mathrm{~A}}$ receptors. Although 5- $\mathrm{HT}_{1 \mathrm{~A}}$ receptors are not necessary for ejaculation during normal copulation, their activation becomes crucial for ejaculation when serotonin levels are elevated. Since serotonin levels can fluctuate under many circumstances, it is possible that this mechanism developed to favour successful copulation when serotonin levels are increased.

\section{Further research}

Although much information has been gathered by either neuroanatomical studies or psychopharmacological experiments, the constructive combination of both fields of science is needed to improve the knowledge of the effects of serotonin on the ejaculatory threshold.

For example, the neuropharmacology of serotonergic neurons in the nPGi involved in the ejaculatory threshold is barely known. It is unclear what triggers the firing of these neurons and what their electrophysiological properties are, and whether they contain $5-\mathrm{HT}_{1 \mathrm{~A}} / 1 \mathrm{~B}$ autoreceptors on their soma or axon terminals. Moreover, it is unknown whether the serotonergic neurons in the nPGi make direct or indirect functional contact with the LSt cells. Interestingly, serotonergic neurons in the $\mathrm{nPGi}$ and serotonergic fibres in the lumbosacral spinal cord co-express substance $\mathrm{P}$ (Hokfelt et al., 2000; Maxwell et al., 1996), a neurotransmitter that binds to neurokinin-1 receptors, which are abundantly present on the LSt cells (Truitt and Coolen,
2002). Substance $P$ has been found to lower the ejaculatory threshold when micro-injected in the medial preoptic/ anterior hypothalamic area (Dornan and Malsbury, 1989). Further research to investigate the functional consequences of this co-expression is required.

It is not yet understood how serotonin influences the ejaculatory threshold in supraspinal areas. Inhibition of dopaminergic neurotransmission might play a role, since dopamine release in the MPOA mediated by the medial amygdala (Dominguez et al., 2001), and in the nucleus accumbens mediated by the lateral hypothalamic area (Lorrain et al., 1999), strongly facilitate ejaculation (Hull et al., 2004). Experiments investigating how serotonin decreases dopamine release in these areas are required.

There are surprisingly few data on the exact role of $5-\mathrm{HT}_{1 \mathrm{~B}}$ and $5-\mathrm{HT}_{2 \mathrm{C}}$ receptors on the ejaculatory threshold. The existence of more selective receptor agonists and antagonists and the improved techniques to make local injections enable innovative experiments on this subject. In addition, the use of knockout mice or creation of knockout rats that lack the $5-\mathrm{HT}_{1 \mathrm{~A}}, 5-\mathrm{HT}_{1 \mathrm{~B}}$ or $5-\mathrm{HT}_{2 \mathrm{C}}$ receptor could further elucidate the role of serotonin on the ejaculatory threshold.

Ultimately, new findings in all these directions might help to design drugs that elevate the ejaculatory threshold in men suffering from lifelong premature ejaculation, or perhaps relieve other ejaculatory disorders.

\section{References}

Abramowski, D., Rigo, M., Duc, D., Hoyer, D., Staufenbiel, M., 1995. Localization of the 5-hydroxytryptamine2C receptor protein in human and rat brain using specific antisera. Neuropharmacology 34, $1635-1645$.

Ago, Y., Nakamura, S., Baba, A., Matsuda, T., 2005. Sulpiride in combination with fluvoxamine increases in vivo dopamine release selectively in rat prefrontal cortex. Neuropsychopharmacology 30 , $43-51$.

Ahlenius, S., Larsson, K., 1984. Failure to antagonize the 8-hydroxy-2-din-propylamino)tetralin-induced facilitation of male rat sexual behavior by the administration of 5-HT receptor antagonists. European Journal of Pharmacology 99, 279-286.

Ahlenius, S., Larsson, K., 1985. Antagonism by lisuride and 8-OH-DPAT of 5-HTP-induced prolongation of the performance of male rat sexual behavior. European Journal of Pharmacology 110, 379-381.

Ahlenius, S., Larsson, K., 1991. Opposite effects of 5-methoxy- $N, N$-dimethyl-tryptamine and 5-hydroxytryptophan on male rat sexual behavior. Pharmacology Biochemistry and Behavior 38, 201-205.

Ahlenius, S., Larsson, K., 1998. Evidence for an involvement of 5-HT 1 B receptors in the inhibition of male rat ejaculatory behavior produced by 5-HTP. Psychopharmacology (Berlin) 137, 374-382.

Ahlenius, S., Larsson, K., 1999. Synergistic actions of the $5-\mathrm{HT}_{1 \mathrm{~A}}$ receptor antagonist WAY-100635 and citalopram on male rat ejaculatory behavior. European Journal of Pharmacology 379, 1-6.

Ahlenius, S., Eriksson, H., Larsson, K., Modigh, K., Sodersten, P., 1971. Mating behavior in the male rat treated with $p$-chlorophenylalanine methyl ester alone and in combination with pargyline. Psychopharmacologia 20, 383-388.

Ahlenius, S., Heimann, M., Larsson, K., 1979. Prolongation of the ejaculation latency in the male rat by thioridazine and chlorimipramine. Psychopharmacology (Berlin) 65, 137-140. 
Ahlenius, S., Larsson, K., Svensson, L., 1980. Further evidence for an inhibitory role of central 5-HT in male rat sexual behavior. Psychopharmacology (Berlin) 68, 217-220.

Ahlenius, S., Larsson, K., Svensson, L., Hjorth, S., Carlsson, A., Lindberg, P., Wikstrom, H., Sanchez, D., Arvidsson, L.E., Hacksell, U., Nilsson, J.L., 1981. Effects of a new type of 5-HT receptor agonist on male rat sexual behavior. Pharmacology Biochemistry and Behavior 15, 785-792.

Albinsson, A., Andersson, G., Andersson, K., Vega-Matuszczyk, J., Larsson, K., 1996. The effects of lesions in the mesencephalic raphe systems on male rat sexual behavior and locomotor activity. Behavioural Brain Research 80, 57-63.

Andersson, G., Larsson, K., 1994. Effects of FG 5893, a new compound with $5-\mathrm{HT}_{1 \mathrm{~A}}$ receptor agonistic and 5 -HT2 receptor antagonistic properties, on male rat sexual behavior. European Journal of Pharmacology 255, 131-137.

Aznar, S., Qian, Z., Shah, R., Rahbek, B., Knudsen, G.M., 2003. The $5-\mathrm{HT}_{1 \mathrm{~A}}$ serotonin receptor is located on calbindin- and parvalbumincontaining neurons in the rat brain. Brain Research 959, 58-67.

Balfour, M.E., Yu, L., Coolen, L.M., 2004. Sexual behavior and sexassociated environmental cues activate the mesolimbic system in male rats. Neuropsychopharmacology 29, 718-730.

Bancila, M., Verge, D., Rampin, O., Backstrom, J.R., Sanders-Bush, E., McKenna, K.E., Marson, L., Calas, A., Giuliano, F., 1999. 5-Hydroxytryptamine2C receptors on spinal neurons controlling penile erection in the rat. Neuroscience 92, 1523-1537.

Bard, J.A., Zgombick, J., Adham, N., Vaysse, P., Branchek, T.A., Weinshank, R.L., 1993. Cloning of a novel human serotonin receptor (5-HT7) positively linked to adenylate cyclase. Journal of Biological Chemistry 268, 23422-23426.

Barnes, N.M., Sharp, T., 1999. A review of central 5-HT receptors and their function. Neuropharmacology 38, 1083-1152.

Baum, M.J., Everitt, B.J., 1992. Increased expression of c-fos in the medial preoptic area after mating in male rats: role of afferent inputs from the medial amygdala and midbrain central tegmental field. Neuroscience 50, 627-646.

Bitran, D., Hull, E.M., 1987. Pharmacological analysis of male rat sexual behavior. Neuroscience and Biobehavioural Reviews 11, 365-389.

Blier, P., Pineyro, G., el Mansari, M., Bergeron, R., de Montigny, C., 1998. Role of somatodendritic 5-HT autoreceptors in modulating 5-HT neurotransmission. Annals of the New York Academy of Sciences 861, 204-216.

Bosker, F.J., Klompmakers, A.A., Westenberg, H.G., 1995. Effects of single and repeated oral administration of fluvoxamine on extracellular serotonin in the median raphe nucleus and dorsal hippocampus of the rat. Neuropharmacology 34, 501-508.

Bressler, S.C., Baum, M.J., 1996. Sex comparison of neuronal Fos immunoreactivity in the rat vomeronasal projection circuit after chemosensory stimulation. Neuroscience 71, 1063-1072.

Bymaster, F.P., Zhang, W., Carter, P.A., Shaw, J., Chernet, E., Phebus, L., Wong, D.T., Perry, K.W., 2002. Fluoxetine, but not other selective serotonin uptake inhibitors, increases norepinephrine and dopamine extracellular levels in prefrontal cortex. Psychopharmacology (Berlin) $160,353-361$.

Cantor, J.M., Binik, Y.M., Pfaus, J.G., 1999. Chronic fluoxetine inhibits sexual behavior in the male rat: reversal with oxytocin. Psychopharmacology (Berlin) 144, 355-362.

Carro-Juarez, M., Rodriguez-Manzo, G., 2000. Sensory and motor aspects of the coital reflex in the spinal male rat. Behavioural Brain Research 108, 97-103.

Casu, M.A., Pisu, C., Lobina, C., Pani, L., 2004. Immunocytochemical study of the forebrain serotonergic innervation in Sardinian alcoholpreferring rats. Psychopharmacology (Berlin) 172, 341-351.

Chambille, I., Rampin, O., 2002. AMPA glutamatergic receptorimmunoreactive subunits are expressed in lumbosacral neurons of the spinal cord and neurons of the dorsal root and pelvic ganglia controlling pelvic functions in the rat. Brain Research 933, 66-80.
Chia, S., 2002. Management of premature ejaculation - a comparison of treatment outcome in patients with and without erectile dysfunction. International Journal of Andrology 25, 301-305.

Chung, S.K., McVary, K.T., McKenna, K.E., 1988. Sexual reflexes in male and female rats. Neuroscience Letters 94, 343-348.

Clark, M.S., Neumaier, J.F., 2001. The 5- $\mathrm{HT}_{1 \mathrm{~B}}$ receptor: behavioral implications. Psychopharmacology Bulletin 35, 170-185.

Clement, P., Bernabe, J., Kia, H.K., Alexandre, L., Giuliano, F., 2005. D2-like receptors mediate the expulsion phase of ejaculation elicited by 8-hydroxy-2-(Di-N-propylamino)tetralin (8-Oh-Dpat) in rats. Journal of Pharmacology and Experimental Therapeutics 316, 830-834.

Clemett, D.A., Punhani, T., Duxon, M.S., Blackburn, T.P., Fone, K.C., 2000. Immunohistochemical localisation of the $5-\mathrm{HT}_{2 \mathrm{C}}$ receptor protein in the rat CNS. Neuropharmacology 39, 123-132.

Collin, M., Backberg, M., Onnestam, K., Meister, B., 2002. 5-HT $1 \mathrm{~A}$ receptor immunoreactivity in hypothalamic neurons involved in body weight control. Neuroreport 13, 945-951.

Coolen, L.M., Peters, H.J., Veening, J.G., 1996. Fos immunoreactivity in the rat brain following consummatory elements of sexual behavior: a sex comparison. Brain Research 738, 67-82.

Coolen, L.M., Olivier, B., Peters, H.J., Veening, J.G., 1997a. Demonstration of ejaculation-induced neural activity in the male rat brain using 5-HT ${ }_{1 \mathrm{~A}}$ agonist 8-OH-DPAT. Physiology \& Behavior 62, 881-891.

Coolen, L.M., Peters, H.J., Veening, J.G., 1997b. Distribution of Fos immunoreactivity following mating versus anogenital investigation in the male rat brain. Neuroscience 77, 1151-1161.

Coolen, L.M., Peters, H.J., Veening, J.G., 1998. Anatomical interrelationships of the medial preoptic area and other brain regions activated following male sexual behavior: a combined fos and tract-tracing study. Journal of Comparative Neurology 397, 421-435.

Coolen, L.M., Veening, J.G., Petersen, D.W., Shipley, M.T., 2003a. Parvocellular subparafascicular thalamic nucleus in the rat: anatomical and functional compartmentalization. Journal of Comparative Neurology 463, 117-131.

Coolen, L.M., Veening, J.G., Wells, A.B., Shipley, M.T., 2003b. Afferent connections of the parvocellular subparafascicular thalamic nucleus in the rat: evidence for functional subdivisions. Journal of Comparative Neurology 463, 132-156.

Coolen, L.M., Allard, J., Pattij, T., McKenna, K.E., 2004a. The Spinal Ejaculation Generator in Male Rats Receives Serotonergic Input and Expresses 5- $\mathrm{HT}_{1 \mathrm{~B}}$ Receptors. Society for Neuroscience, Online Abstract Viewer, Program Nr 998.1, Washington, DC.

Coolen, L.M., Allard, J., Truitt, W.A., McKenna, K.E., 2004b. Central regulation of ejaculation. Physiology \& Behavior 83, 203-215.

Dahlof, L.G., Larsson, K., 1979. PCPA potentiates the effects of specific copulatory experience on the sexual behavior of the pudendectomized male rat. Pharmacology Biochemistry and Behavior 11, 701-704.

de Jong, T.R., Pattij, T., Veening, J.G., Dederen, P.J., Waldinger, M.D., Cools, A.R., Olivier, B., 2005a. Citalopram combined with WAY 100635 inhibits ejaculation and ejaculation-related Fos immunoreactivity. European Journal of Pharmacology 509, 49-59.

de Jong, T.R., Pattij, T., Veening, J.G., Waldinger, M.D., Cools, A.R., Olivier, B., 2005b. Effects of chronic selective serotonin reuptake inhibitors on 8-OH-DPAT-induced facilitation of ejaculation in rats: comparison of fluvoxamine and paroxetine. Psychopharmacology (Berlin) 179, 509-515.

Denys, D., Klompmakers, A.A., Westenberg, H.G., 2004. Synergistic dopamine increase in the rat prefrontal cortex with the combination of quetiapine and fluvoxamine. Psychopharmacology (Berlin) 176, 195-203.

Dominguez, J., Riolo, J.V., Xu, Z., Hull, E.M., 2001. Regulation by the medial amygdala of copulation and medial preoptic dopamine release. Journal of Neuroscience 21, 349-355.

Dornan, W.A., Malsbury, C.W., 1989. Peptidergic control of male rat sexual behavior: the effects of intracerebral injections of substance $\mathrm{P}$ and cholecystokinin. Physiology \& Behavior 46, 547-556. 
Drago, F., Busa, L., Benelli, A., Bertolini, A., 1999. Acute low doses of melatonin stimulate rat sex behavior: the role of serotonin neurotransmission. European Journal of Pharmacology 385, 1-6.

Duran, I.D., Rojas-Piloni, J.G., Cueva-Rolon, R., 1997. Facilitation and inhibition of the urethrogenital reflex in spinal cord-transected rats. Brain Research 775, 1-10.

Duran, I., Gil, L., Cueva-Rolon, R., 2000. Masculine copulatory behavior is facilitated by intrathecally administered muscarine. Experimental Brain Research 134, 490-496.

Elena Castro, M., Diaz, A., del Olmo, E., Pazos, A., 2003. Chronic fluoxetine induces opposite changes in $\mathrm{G}$ protein coupling at pre and postsynaptic $5-\mathrm{HT}_{1 \mathrm{~A}}$ receptors in rat brain. Neuropharmacology 44 , 93-101.

Felton, T.M., Kang, T.B., Hjorth, S., Auerbach, S.B., 2003. Effects of selective serotonin and serotonin/noradrenaline reuptake inhibitors on extracellular serotonin in rat diencephalon and frontal cortex. Naunyn Schmiedebergs Archives of Pharmacology 367, 297-305.

Fernandez-Guasti, A., Escalante, A., 1991. Role of presynaptic serotonergic receptors on the mechanism of action of 5- $\mathrm{HT}_{1 \mathrm{~A}}$ and $5-\mathrm{HT}_{1 \mathrm{~B}}$ agonists on masculine sexual behaviour: physiological and pharmacological implications. Journal of Neural Transmission - General Section $85,95-107$.

Fernandez-Guasti, A., Rodriguez-Manzo, G., 1992. Further evidence showing that the inhibitory action of serotonin on rat masculine sexual behavior is mediated after the stimulation of $5-\mathrm{HT}_{1 \mathrm{~B}}$ receptors. Pharmacology Biochemistry and Behavior 42, 529-533.

Fernandez-Guasti, A., Rodriguez-Manzo, G., 1997. 8-OH-DPAT and male rat sexual behavior: partial blockade by noradrenergic lesion and sexual exhaustion. Pharmacology Biochemistry and Behavior 56, $111-116$.

Fernandez-Guasti, A., Hansen, S., Archer, T., Jonsson, G., 1986. Noradrenaline-serotonin interactions in the control of sexual behavior in the male rat: DSP4-induced noradrenaline depletion antagonizes the facilitatory effect of serotonin receptor agonists, 5-MeODMT and lisuride. Brain Research 377, 112-118.

Fernandez-Guasti, A., Escalante, A., Agmo, A., 1989. Inhibitory action of various $5-\mathrm{HT}_{1 \mathrm{~B}}$ receptor agonists on rat masculine sexual behaviour. Pharmacology Biochemistry and Behavior 34, 811-816.

Fernandez-Guasti, A., Escalante, A.L., Ahlenius, S., Hillegaart, V., Larsson, K., 1992a. Stimulation of $5-\mathrm{HT}_{1 \mathrm{~A}}$ and $5-\mathrm{HT}_{1 \mathrm{~B}}$ receptors in brain regions and its effects on male rat sexual behaviour. European Journal of Pharmacology 210, 121-129.

Fernandez-Guasti, A., Escalante, A.L., Ahlenius, S., Hillegaart, V., Larsson, K., 1992b. Stimulation of $5-\mathrm{HT}_{1 \mathrm{~A}}$ and $5-\mathrm{HT}_{1 \mathrm{~B}}$ receptors in brain regions and its effects on male rat sexual behaviour. European Journal of Pharmacology 210, 121-129.

Fonseca, M.I., Ni, Y.G., Dunning, D.D., Miledi, R., 2001. Distribution of serotonin $2 \mathrm{~A}, 2 \mathrm{C}$ and 3 receptor mRNA in spinal cord and medulla oblongata. Brain Research Molecular Brain Research 89, 11-19.

Foreman, M.M., Hall, J.L., Love, R.L., 1989. The role of the 5-HT2 receptor in the regulation of sexual performance of male rats. Life Sciences 45, 1263-1270.

Foreman, M.M., Hall, J.L., Love, R.L., 1992. Effects of fenfluramine and para-chloroamphetamine on sexual behavior of male rats. Psychopharmacology (Berlin) 107, 327-330.

Gardier, A.M., Trillat, A.C., Malagie, I., Jacquot, C., 1994. 8-OH-DPAT attenuates the dexfenfluramine-induced increase in extracellular serotonin: an in vivo dialysis study. European Journal of Pharmacology $265,107-110$.

Gartside, S.E., Cowen, P.J., Sharp, T., 1992. Effect of 5-hydroxy-Ltryptophan on the release of 5-HT in rat hypothalamus in vivo as measured by microdialysis. Neuropharmacology 31, 9-14.

Gerendai, I., Toth, I.E., Kocsis, K., Boldogkoi, Z., Rusvai, M., Halasz, B., 2001. Identification of CNS neurons involved in the innervation of the epididymis: a viral transneuronal tracing study. Autonomic Neuroscience $92,1-10$.

Gessa, G.L., Tagliamonte, A., 1974. Role of brain monoamines in male sexual behavior. Life Sciences 14, 425-436.
Gobert, A., Rivet, J.M., Audinot, V., Newman-Tancredi, A., Cistarelli, L., Millan, M.J., 1998. Simultaneous quantification of serotonin, dopamine and noradrenaline levels in single frontal cortex dialysates of freely moving rats reveals a complex pattern of reciprocal auto- and heteroreceptor-mediated control of release. Neuroscience 84, 413-429.

Gottsch, M.L., Clifton, D.K., Steiner, R.A., 2004. Galanin-like peptide as a link in the integration of metabolism and reproduction. Trends in Endocrinology and Metabolism 15, 215-221.

Greco, B., Edwards, D.A., Michael, R.P., Clancy, A.N., 1996. Androgen receptor immunoreactivity and mating-induced Fos expression in forebrain and midbrain structures in the male rat. Neuroscience 75 , $161-171$.

Gregorian, R.S., Golden, K.A., Bahce, A., Goodman, C., Kwong, W.J., Khan, Z.M., 2002. Antidepressant-induced sexual dysfunction. Annals of the Pharmacotherapy 36, 1577-1589.

Haensel, S.M., Slob, A.K., 1997. Flesinoxan: a prosexual drug for male rats. European Journal of Pharmacology 330, 1-9.

Hajos, M., Hajos-Korcsok, E., Sharp, T., 1999. Role of the medial prefrontal cortex in 5- $\mathrm{HT}_{1 \mathrm{~A}}$ receptor-induced inhibition of 5-HT neuronal activity in the rat. British Journal of Pharmacology 126, $1741-1750$.

Hajos-Korcsok, E., McTavish, S.F., Sharp, T., 2000. Effect of a selective 5-hydroxytryptamine reuptake inhibitor on brain extracellular noradrenaline: microdialysis studies using paroxetine. European Journal of Pharmacology 407, 101-107.

Hansen, S., Kohler, C., Goldstein, M., Steinbusch, H.V., 1982. Effects of ibotenic acid-induced neuronal degeneration in the medial preoptic area and the lateral hypothalamic area on sexual behavior in the male rat. Brain Research 239, 213-232.

Hartmann, U., Waldinger, M.D., 2005. Ejaculatory disorders. World Journal of Urology 23, 67.

Heeb, M.M., Yahr, P., 2001. Anatomical and functional connections among cell groups in the gerbil brain that are activated with ejaculation. Journal of Comparative Neurology 439, 248-258.

Helke, C.J., Capuano, S., Tran, N., Zhuo, H., 1997. Immunocytochemical studies of the 5-HT(1A) receptor in ventral medullaryneurons that project to the intermediolateral cell column and contain serotonin or tyrosine hydroxylase immunoreactivity. Journal of Comparative Neurology 379, 261-270.

Hensler, J.G., 2003. Regulation of $5-\mathrm{HT}_{1 \mathrm{~A}}$ receptor function in brain following agonist or antidepressant administration. Life Sciences 72, $1665-1682$.

Hervas, I., Artigas, F., 1998. Effect of fluoxetine on extracellular 5-hydroxytryptamine in rat brain. Role of 5-HT autoreceptors. European Journal of Pharmacology 358, 9-18.

Hillegaart, V., Ahlenius, S., 1998. Facilitation and inhibition of male rat ejaculatory behaviour by the respective $5-\mathrm{HT}_{1 \mathrm{~A}}$ and $5-\mathrm{HT}_{1 \mathrm{~B}}$ receptor agonists 8-OH-DPAT and anpirtoline, as evidenced by use of the corresponding new and selective receptor antagonists NAD-299 and NAS-181. British Journal of Pharmacology 125, 1733-1743.

Hillegaart, V., Ahlenius, S., Larsson, K., 1989. Effects of local application of 5-HT into the median and dorsal raphe nuclei on male rat sexual and motor behavior. Behavioural Brain Research 33, 279-286.

Hillegaart, V., Ahlenius, S., Larsson, K., 1991. Region-selective inhibition of male rat sexual behavior and motor performance by localized forebrain 5-HT injections: a comparison with effects produced by 8-OH-DPAT. Behavioural Brain Research 42, 169-180.

Hjorth, S., Sharp, T., 1991. Effect of the 5- $\mathrm{HT}_{1 \mathrm{~A}}$ receptor agonist 8-OHDPAT on the release of 5-HT in dorsal and median raphe-innervated rat brain regions as measured by in vivo microdialysis. Life Sciences 48, 1779-1786.

Hokfelt, T., Arvidsson, U., Cullheim, S., Millhorn, D., Nicholas, A.P., Pieribone, V., Seroogy, K., Ulfhake, B., 2000. Multiple messengers in descending serotonin neurons: localization and functional implications. Journal of Chemical Neuroanatomy 18, 75-86.

Hughes, Z.A., Starr, K.R., Langmead, C.J., Hill, M., Bartoszyk, G.D., Hagan, J.J., Middlemiss, D.N., Dawson, L.A., 2005. Neurochemical evaluation of the novel 5-HT(1A) receptor partial agonist/serotonin 
reuptake inhibitor, vilazodone. European Journal of Pharmacology $510,49-57$.

Hull, E.M., Muschamp, J.W., Sato, S., 2004. Dopamine and serotonin: influences on male sexual behavior. Physiology \& Behavior 83, 291-307.

Humphries, C.R., Paxinos, G., O’Brien, M., 1981. Mechanisms of PCAinduced hypothermia, ejaculation, salivation and irritability in rats. Pharmacology Biochemistry and Behavior 15, 197-200.

Invernizzi, R., Bramante, M., Samanin, R., 1995. Extracellular concentrations of serotonin in the dorsal hippocampus after acute and chronic treatment with citalopram. Brain Research 696, 62-66.

Invernizzi, R., Bramante, M., Samanin, R., 1996. Role of 5-HT $1 \mathrm{~A}$ receptors in the effects of acute chronic fluoxetine on extracellular serotonin in the frontal cortex. Pharmacology Biochemistry and Behavior 54, 143-147.

Kara, H., Aydin, S., Yucel, M., Agargun, M.Y., Odabas, O., Yilmaz, Y., 1996. The efficacy of fluoxetine in the treatment of premature ejaculation: a double-blind placebo controlled study. Journal of Urology 156, 1631-1632.

Kia, H.K., Miquel, M.C., Brisorgueil, M.J., Daval, G., Riad, M., El Mestikawy, S., Hamon, M., Verge, D., 1996. Immunocytochemical localization of serotonin1A receptors in the rat central nervous system. Journal of Comparative Neurology 365, 289-305.

Kim, S.C., Seo, K.K., 1998. Efficacy and safety of fluoxetine, sertraline and clomipramine in patients with premature ejaculation: a doubleblind, placebo controlled study. Journal of Urology 159, 425-427.

Kimura, Y., Kisaki, N., Sakurada, S., Tadano, T., 1977. On the brain monoaminergic systems relatint to ejaculation. II. Brain serotonin and ejaculation. Andrologia 9, 50-54.

Kimura, Y., Miyamoto, A., Urano, S., Yonezawa, A., Tadano, T., Kisara, K., 1983. The spinal monoaminergic systems relating to ejaculation. II. Ejaculation and serotonin. Andrologia 15, 222-227.

Kippin, T.E., Sotiropoulos, V., Badih, J., Pfaus, J.G., 2004. Opposing roles of the nucleus accumbens and anterior lateral hypothalamic area in the control of sexual behaviour in the male rat. European Journal of Neuroscience 19, 698-704.

Klint, T., Larsson, K., 1995. Clozapine acts as a 5-HT2 antagonist by attenuating DOI-induced inhibition of male rat sexual behaviour. Psychopharmacology (Berlin) 119, 291-294.

Klint, T., Dahlgren, I.L., Larsson, K., 1992. The selective 5-HT2 receptor antagonist amperozide attenuates 1-(2,5-dimethoxy-4-iodophenyl)-2aminopropane-induced inhibition of male rat sexual behavior. European Journal of Pharmacology 212, 241-246.

Kondo, Y., Yamanouchi, K., 1995. The possible involvement of the nonstrial pathway of the amygdala in neural control of sexual behavior in male rats. Brain Research Bulletin 38, 37-40.

Larsen, P.J., Hay-Schmidt, A., Vrang, N., Mikkelsen, J.D., 1996. Origin of projections from the midbrain raphe nuclei to the hypothalamic paraventricular nucleus in the rat: a combined retrograde and anterograde tracing study. Neuroscience 70, 963-988.

Larsson, K., Ahlenius, S., 1999. Brain and sexual behavior. Annals of the New York Academy of Science 877, 292-308.

Le Poul, E., Laaris, N., Doucet, E., Laporte, A.M., Hamon, M., Lanfumey, L., 1995. Early desensitization of somato-dendritic $5-\mathrm{HT}_{1 \mathrm{~A}}$ autoreceptors in rats treated with fluoxetine or paroxetine. Naunyn Schmiedebergs Archives of Pharmacology 352, 141-148.

Le Poul, E., Boni, C., Hanoun, N., Laporte, A.M., Laaris, N., Chauveau, J., Hamon, M., Lanfumey, L., 2000. Differential adaptation of brain $5-\mathrm{HT}_{1 \mathrm{~A}}$ and $5-\mathrm{HT}_{1 \mathrm{~B}}$ receptors and 5-HT transporter in rats treated chronically with fluoxetine. Neuropharmacology 39, $110-122$.

Lee, R.L., Smith, E.R., Mas, M., Davidson, J.M., 1990. Effects of intrathecal administration of 8-OH-DPAT on genital reflexes and mating behavior in male rats. Physiology \& Behavior 47, 665-669.

Li, Q., Battaglia, G., Van de Kar, L.D., 1997a. Autoradiographic evidence for differential G-protein coupling of 5- $\mathrm{HT}_{1 \mathrm{~A}}$ receptors in rat brain: lack of effect of repeated injections of fluoxetine. Brain Research 769, $141-151$.
Li, Q., Muma, N.A., Battaglia, G., Van de Kar, L.D., 1997b. A desensitization of hypothalamic $5-\mathrm{HT}_{1 \mathrm{~A}}$ receptors by repeated injections of paroxetine: reduction in the levels of $G(\mathrm{i})$ and $\mathrm{G}(\mathrm{o})$ proteins and neuroendocrine responses, but not in the density of $5-\mathrm{HT}_{1 \mathrm{~A}}$ receptors. Journal of Pharmacology and Experimental Therapeutics 282, 1581-1590.

Liu, Y.C., Salamone, J.D., Sachs, B.D., 1997a. Impaired sexual response after lesions of the paraventricular nucleus of the hypothalamus in male rats. Behavioral Neuroscience 111, 1361-1367.

Liu, Y.C., Salamone, J.D., Sachs, B.D., 1997b. Lesions in medial preoptic area and bed nucleus of stria terminalis: differential effects on copulatory behavior and noncontact erection in male rats. Journal of Neuroscience 17, 5245-5253.

Looney, C., Thor, K.B., Ricca, D., Marson, L., 2005. Differential effects of simultaneous or sequential administration of paroxetine and WAY100,635 on ejaculatory behavior. Pharmacology Biochemistry and Behavior 82, 427-433.

Lorrain, D.S., Matuszewich, L., Friedman, R.D., Hull, E.M., 1997. Extracellular serotonin in the lateral hypothalamic area is increased during the postejaculatory interval and impairs copulation in male rats. Journal of Neuroscience 17, 9361-9366.

Lorrain, D.S., Matuszewich, L., Hull, E.M., 1998. 8-OH-DPAT influences extracellular levels of serotonin and dopamine in the medial preoptic area of male rats. Brain Research 790, 217-223.

Lorrain, D.S., Riolo, J.V., Matuszewich, L., Hull, E.M., 1999. Lateral hypothalamic serotonin inhibits nucleus accumbens dopamine: implications for sexual satiety. Journal of Neuroscience 19, 7648-7652.

Magoul, R., Ciofi, P., Tramu, G., 1994. Visualization of an efferent projection route of the hypothalamic rat arcuate nucleus through the stria terminalis after labeling with carbocyanine dye (DiI) or proopiomelanocortin-immunohistochemistry. Neuroscience Letters $172,134-138$.

Makarenko, I.G., Meguid, M.M., Ugrumov, M.V., 2002. Distribution of serotonin 5-hydroxytriptamine $1 \mathrm{~B}\left(5-\mathrm{HT}_{1 \mathrm{~B}}\right)$ receptors in the normal rat hypothalamus. Neuroscience Letters 328, 155-159.

Malagie, I., Trillat, A.C., Jacquot, C., Gardier, A.M., 1995. Effects of acute fluoxetine on extracellular serotonin levels in the raphe: an in vivo microdialysis study. European Journal of Pharmacology 286, 213-217.

Malagie, I., Deslandes, A., Gardier, A.M., 2000. Effects of acute and chronic tianeptine administration on serotonin outflow in rats: comparison with paroxetine by using in vivo microdialysis. European Journal of Pharmacology 403, 55-65.

Marson, L., 2004. Lesions of the periaqueductal gray block the medial preoptic area-induced activation of the urethrogenital reflex in male rats. Neuroscience Letters 367, 278-282.

Marson, L., Gravitt, K., 2004. Spinal neurons activated with the urethrogenital reflex in the male rat. Brain Research 1026, 108-115.

Marson, L., McKenna, K.E., 1990. The identification of a brainstem site controlling spinal sexual reflexes in male rats. Brain Research 515, 303-308.

Marson, L., McKenna, K.E., 1992. A role for 5-hydroxytryptamine in descending inhibition of spinal sexual reflexes. Experimental Brain Research 88, 313-320.

Marson, L., McKenna, K.E., 1994a. Serotonergic neurotoxic lesions facilitate male sexual reflexes. Pharmacology Biochemistry and Behavior 47, 883-888.

Marson, L., McKenna, K.E., 1994b. Stimulation of the hypothalamus initiates the urethrogenital reflex in male rats. Brain Research 638, 103-108.

Marson, L., McKenna, K.E., 1996. CNS cell groups involved in the control of the ischiocavernosus and bulbospongiosus muscles: a transneuronal tracing study using pseudorabies virus. Journal of Comparative Neurology 374, 161-179.

Marson, L., Platt, K.B., McKenna, K.E., 1993. Central nervous system innervation of the penis as revealed by the transneuronal transport of pseudorabies virus. Neuroscience 55, 263-280. 
Mas, M., Zahradnik, M.A., Martino, V., Davidson, J.M., 1985. Stimulation of spinal serotonergic receptors facilitates seminal emission and suppresses penile erectile reflexes. Brain Research 342, $128-134$.

Mathes, C.W., Smith, E.R., Popa, B.R., Davidson, J.M., 1990. Effects of intrathecal and systemic administration of buspirone on genital reflexes and mating behavior in male rats. Pharmacology Biochemistry and Behavior 36, 63-68.

Matuszewich, L., Lorrain, D.S., Trujillo, R., Dominguez, J., Putnam, S.K., Hull, E.M., 1999. Partial antagonism of 8-OH-DPAT'S effects on male rat sexual behavior with a $\mathrm{D} 2$, but not a $5-\mathrm{HT}_{1 \mathrm{~A}}$, antagonist. Brain Research 820, 55-62.

Maxwell, L., Maxwell, D.J., Neilson, M., Kerr, R., 1996. A confocal microscopic survey of serotoninergic axons in the lumbar spinal cord of the rat: co-localization with glutamate decarboxylase and neuropeptides. Neuroscience 75, 471-480.

McIntosh, T.K., Barfield, R.J., 1984. Brain monoaminergic control of male reproductive behavior. I. Serotonin and the post-ejaculatory refractory period. Behavioural Brain Research 12, 255-265.

McKenna, K.E., 2000. Some proposals regarding the organization of the central nervous system control of penile erection. Neuroscience and Biobehavioural Reviews 24, 535-540.

McKenna, K.E., Nadelhaft, I., 1986. The organization of the pudendal nerve in the male and female rat. Journal of Comparative Neurology 248, 532-549.

McKenna, K.E., Chung, S.K., McVary, K.T., 1991. A model for the study of sexual function in anesthetized male and female rats. American Journal of Physiology 261, R1276-R1285.

McMahon, C.G., Abdo, C., Incrocci, L., Perelman, M., Rowland, D., Waldinger, M.D., Xin, Z.C., 2004. Disorders of orgasm and ejaculation in men. Journal of Sex and Medicicne 1, 58-65.

Meisel, R.L., Sachs, B.D., 1994. The physiology of male sexual behavior. In: Knobil, E., Neill, J.D., Greenwald, G.S., Markert, C.L., Pfaff, D.W. (Eds.), The Physiology of Reproduction, vol. 2. Raven Press, Ltd., New York, pp. 3-105.

Mendelson, S.D., Gorzalka, B.B., 1986. 5-HT $1 \mathrm{~A}$ receptors: differential involvement in female and male sexual behavior in the rat. Physiology \& Behavior 37, 345-351.

Mendelson, S.D., Gorzalka, B.B., 1990. Sex differences in the effects of 1 -(m-trifluoromethylphenyl) piperazine and 1-(m-chlorophenyl) piperazine on copulatory behavior in the rat. Neuropharmacology 29, $783-786$.

Montgomery, S.A., Baldwin, D.S., Riley, A., 2002. Antidepressant medications: a review of the evidence for drug-induced sexual dysfunction. Journal of Affective Disorders 69, 119-140

Morali, G., Larsson, K., 1984. Differential effects of a new serotoninomimetic drug, 8-OH-DPAT, on copulatory behavior and pelvic thrusting pattern in the male rat. Pharmacology Biochemistry and Behavior 20, 185-187.

Moreland, A.J., Makela, E.H., 2005. Selective serotonin-reuptake inhibitors in the treatment of premature ejaculation. Annals of the Pharmacotherapy 39, 1296-1301.

Moret, C., Briley, M., 1996. Effects of acute and repeated administration of citalopram on extracellular levels of serotonin in rat brain European Journal of Pharmacology 295, 189-197.

Mos, J., Mollet, I., Tolboom, J.T., Waldinger, M.D., Olivier, B., 1999. A comparison of the effects of different serotonin reuptake blockers on sexual behaviour of the male rat. European Neuropsychopharmacology $9,123-135$.

Murphy, A.Z., Hoffman, G.E., 2001. Distribution of gonadal steroid receptor-containing neurons in the preoptic-periaqueductal graybrainstem pathway: a potential circuit for the initiation of male sexual behavior. Journal of Comparative Neurology 438, 191-212.

Murphy, A.Z., Rizvi, T.A., Ennis, M., Shipley, M.T., 1999. The organization of preoptic-medullary circuits in the male rat: evidence for interconnectivity of neural structures involved in reproductive behavior, antinociception and cardiovascular regulation. Neuroscience $91,1103-1116$
Nakayama, K., 2002. Effect of paroxetine on extracellular serotonin and dopamine levels in the prefrontal cortex. Naunyn Schmiedebergs Archives of Pharmacology 365, 102-105.

Neumaier, J.F., Szot, P., Peskind, E.R., Dorsa, D.M., Hamblin, M.W., 1996. Serotonergic lesioning differentially affects presynaptic and postsynaptic $5-\mathrm{HT}_{1 \mathrm{~B}}$ receptor mRNA levels in rat brain. Brain Research 722, 50-58.

Neumaier, J.F., Sexton, T.J., Yracheta, J., Diaz, A.M., Brownfield, M., 2001. Localization of 5-HT(7) receptors in rat brain by immunocytochemistry, in situ hybridization, and agonist stimulated $\mathrm{cFos}$ expression. Journal of Chemical Neuroanatomy 21, 63-73.

Newman, M.E., Shalom, G., Ran, A., Gur, E., Van de Kar, L.D., 2004. Chronic fluoxetine-induced desensitization of $5-\mathrm{HT}_{1 \mathrm{~A}}$ and $5-\mathrm{HT}_{1 \mathrm{~B}}$ autoreceptors: regional differences and effects of WAY-100635. European Journal of Pharmacology 486, 25-30.

Olivier, B., Chan, J.S., Pattij, T., de Jong, T.R., Oosting, R.S., Veening, J.G., Waldinger, M.D., 2005. Psychopharmacology of male rat sexual behavior: modeling human sexual dysfunctions? International Journal of Impotence Research, in press.

Orr, R., Marson, L., 1998. Identification of CNS neurons innervating the rat prostate: a transneuronal tracing study using pseudorabies virus. Journal of Autonomic Nervous System 72, 4-15.

Paredes, R.G., Highland, L., Karam, P., 1993. Socio-sexual behavior in male rats after lesions of the medial preoptic area: evidence for reduced sexual motivation. Brain Research 618, 271-276.

Paredes, R.G., Kica, E., Baum, M.J., 1994. Differential effects of the serotonin1A agonist, 8-OH-DPAT, on masculine and feminine sexual behavior of the ferret. Psychopharmacology (Berlin) 114, 591-596.

Paredes, R.G., Contreras, J.L., Agmo, A., 2000. Serotonin and sexual behavior in the male rabbit. Journal of Neural Transmission 107, 767-777.

Parfitt, D.B., Newman, S.W., 1998. Fos-immunoreactivity within the extended amygdala is correlated with the onset of sexual satiety. Hormones and Behavior 34, 17-29.

Pattij, T., de Jong, T.R., Uitterdijk, A., Waldinger, M.D., Veening, J.G., Cools, A.R., van der Graaf, P.H., Olivier, B., 2005. Individual differences in male rat ejaculatory behaviour: searching for models to study ejaculation disorders. European Journal of Neuroscience 22, 724-734.

Paxinos, G., Watson, C., 1998. The Rat Brain in Stereotaxic Coordinates, fourth ed. Elsevier Academic Press, San Diego.

Pfaus, J.G., 1996. Frank A. Beach award. Homologies of animal and human sexual behaviors. Hormones and Behavior 30, 187-200.

Pineyro, G., Blier, P., 1999. Autoregulation of serotonin neurons: role in antidepressant drug action. Pharmacological Reviews 51, 533-591.

Pompeiano, M., Palacios, J.M., Mengod, G., 1992. Distribution and cellular localization of mRNA coding for $5-\mathrm{HT}_{1 \mathrm{~A}}$ receptor in the rat brain: correlation with receptor binding. Journal of Neuroscience 12, $440-453$.

Pomerantz, S.M., Hepner, B.C., Wertz, J.M., 1993a. 5-HT $\mathrm{HA}_{1 \mathrm{~A}}$ and 5-HT1C/1D receptor agonists produce reciprocal effects on male sexual behavior of rhesus monkeys. European Journal of Pharmacology 243, 227-234.

Pomerantz, S.M., Hepner, B.C., Wertz, J.M., 1993b. Serotonergic influences on male sexual behavior of rhesus monkeys: effects of serotonin agonists. Psychopharmacology (Berlin) 111, 47-54.

Powell, W.S., Dominguez, J.M., Hull, E.M., 2003. An NMDA antagonist impairs copulation and the experience-induced enhancement of male sexual behavior in the rat. Behavioral Neuroscience 117, 69-75.

Price, G.W., Roberts, C., Watson, J., Burton, M., Mulholland, K., Middlemiss, D.N., Jones, B.J., 1996. Species differences in 5-HT autoreceptors. Behavioural Brain Research 73, 79-82.

Qureshi, G.A., Forsberg, G., Bednar, I., Sodersten, P., 1989. Tryptophan, 5-HTP, 5-HT and 5-HIAA in the cerebrospinal fluid and sexual behavior in male rats. Neuroscience Letters 97, 227-231.

Ranson, R.N., Dodds, A.L., Smith, M.J., Santer, R.M., Watson, A.H., 2003. Age-associated changes in the monoaminergic innervation of rat lumbosacral spinal cord. Brain Research 972, 149-158. 
Raymond, J.R., Mukhin, Y.V., Gelasco, A., Turner, J., Collinsworth, G., Gettys, T.W., Grewal, J.S., Garnovskaya, M.N., 2001. Multiplicity of mechanisms of serotonin receptor signal transduction. Pharmacology \& Therapeutics 92, 179-212.

Rehman, J., Kaynan, A., Christ, G., Valcic, M., Maayani, S., Melman, A., 1999. Modification of sexual behavior of Long-Evans male rats by drugs acting on the 5- $\mathrm{HT}_{1 \mathrm{~A}}$ receptor. Brain Research 821, 414-425.

Renyi, L., 1985. Ejaculations induced by $p$-chloroamphetamine in the rat. Neuropharmacology 24, 697-704.

Rinken, A., Ferre, S., Terasmaa, A., Owman, C., Fuxe, K., 1999. Serotonergic agonists behave as partial agonists at the dopamine D2 receptor. Neuroreport 10, 493-495.

Rodriguez, M., Castro, R., Hernandez, G., Mas, M., 1984. Different roles of catecholaminergic and serotoninergic neurons of the medial forebrain bundle on male rat sexual behavior. Physiology \& Behavior 33, 5-11.

Rodriguez-Manzo, G., Lopez-Rubalcava, C., Hen, R., Fernandez-Guasti, A., 2002. Participation of 5- $\mathrm{HT}_{1 \mathrm{~B}}$ receptors in the inhibitory actions of serotonin on masculine sexual behaviour of mice: pharmacological analysis in 5-HT $1 \mathrm{~B}$ receptor knockout mice. British Journal of Pharmacology 136, 1127-1134.

Rosen, R.C., Lane, R.M., Menza, M., 1999. Effects of SSRIs on sexual function: a critical review. Journal of Clinical Psychopharmacology 19, 67-85.

Salis, P.J., Dewsbury, D.A., 1971. p-Chlorophenylalanine facilitates copulatory behaviour in male rats. Nature 232, 400-401.

Samathanam, G., Duffy, P., Kalivas, P.W., White, S.R., 1989. A comparison of 5-hydroxytryptophan effects on rat lumbar spinal cord serotonin release and monosynaptic response amplitude. Brain Research 501, 179-182.

Sarhan, H., Fillion, G., 1999. Differential sensitivity of 5-HT 1 в auto and heteroreceptors. Naunyn Schmiedebergs Archives of Pharmacology $360,382-390$.

Sari, Y., 2004. Serotonin1B receptors: from protein to physiological function and behavior. Neuroscience and Biobehavioural Reviews 28, $565-582$.

Schnur, S.L., Smith, E.R., Lee, R.L., Mas, M., Davidson, J.M., 1989. A component analysis of the effects of DPAT on male rat sexual behavior. Physiology \& Behavior 45, 897-901.

Schwartz, D., Hernandez, L., Hoebel, B.G., 1989. Fenfluramine administered systemically or locally increases extracellular serotonin in the lateral hypothalamus as measured by microdialysis. Brain Research 482, 261-270.

Series, H.G., Cowen, P.J., Sharp, T., 1994. p-Chloroamphetamine (PCA), 3,4-methylenedioxy-methamphetamine (MDMA) and d-fenfluramine pretreatment attenuates d-fenfluramine-evoked release of 5-HT in vivo. Psychopharmacology (Berlin) 116, 508-514.

Shimizu, N., Take, S., Hori, T., Oomura, Y., 1992. In vivo measurement of hypothalamic serotonin release by intracerebral microdialysis: significant enhancement by immobilization stress in rats. Brain Research Bulletin 28, 727-734.

Sprouse, J., Clarke, T., Reynolds, L., Heym, J., Rollema, H., 1996. Comparison of the effects of sertraline and its metabolite desmethylsertraline on blockade of central 5-HT reuptake in vivo. Neuropsychopharmacology 14, 225-231.

Steers, W.D., 2000. Neural pathways and central sites involved in penile erection: neuroanatomy and clinical implications. Neuroscience and Biobehavioural Reviews 24, 507-516.

Steinbusch, H.W., 1981. Distribution of serotonin-immunoreactivity in the central nervous system of the rat-cell bodies and terminals. Neuroscience 6, 557-618.

Steinbusch, H.W., Nieuwenhuys, R., 1981. Localization of serotonin-like immunoreactivity in the central nervous system and pituitary of the rat, with special references to the innervation of the hypothalamus. Advances in Experimental Medicine and Biology 133, 7-35.

Stoneham, M.D., Everitt, B.J., Hansen, S., Lightman, S.L., Todd, K., 1985. Oxytocin and sexual behaviour in the male rat and rabbit. Jurnal of Endocrinology 107, 97-106.
Sura, A., Overstreet, D.H., Marson, L., 2001. Selectively bred male rat lines differ in naive and experienced sexual behavior. Physiology \& Behavior 72, 13-20.

Svensson, L., Hansen, S., 1984. Spinal monoaminergic modulation of masculine copulatory behavior in the rat. Brain Research 302, 315-321.

Tang, Y., Rampin, O., Calas, A., Facchinetti, P., Giuliano, F., 1998. Oxytocinergic and serotonergic innervation of identified lumbosacral nuclei controlling penile erection in the male rat. Neuroscience 82 , 241-254.

Tang, Y., Rampin, O., Giuliano, F., Ugolini, G., 1999. Spinal and brain circuits to motoneurons of the bulbospongiosus muscle: retrograde transneuronal tracing with rabies virus. Journal of Comparative Neurology 414, 167-192.

Thor, K.B., Nickolaus, S., Helke, C.J., 1993. Autoradiographic localization of 5-hydroxytryptamine1A, 5-hydroxytryptamine1B and 5-hydroxytryptamine $1 \mathrm{C} / 2$ binding sites in the rat spinal cord. Neuroscience 55 , 235-252.

Truitt, W.A., Coolen, L.M., 2002. Identification of a potential ejaculation generator in the spinal cord. Science 297, 1566-1569.

Tsutsui, Y., Shinoda, A., Kondo, Y., 1994. Facilitation of copulatory behavior by pCPA treatments following stria terminalis transection but not medial amygdala lesion in the male rat. Physiology \& Behavior 56, 603-608.

Ueyama, T., Arakawa, H., Mizuno, N., 1987. Central distribution of efferent and afferent components of the pudendal nerve in rat. Anatomy and Embryology (Berlin) 177, 37-49.

van de Kar, L.D., Lorens, S.A., 1979. Differential serotonergic innervation of individual hypothalamic nuclei and other forebrain regions by the dorsal and median midbrain raphe nuclei. Brain Research 162, $45-54$.

Vega, M.J., Larsson, K., Eriksson, E., 1998. The selective serotonin reuptake inhibitor fluoxetine reduces sexual motivation in male rats. Pharmacology Biochemistry and Behavior 60, 527-532.

Verma, S., Chhina, G.S., Mohan Kumar, V., Singh, B., 1989. Inhibition of male sexual behavior by serotonin application in the medial preoptic area. Physiology \& Behavior 46, 327-330.

Waldinger, M.D., 2003. Towards evidence-based drug treatment research on premature ejaculation: a critical evaluation of methodology. International Journal of Impotence Research 15, 309-313.

Waldinger, M.D., 2005. Lifelong premature ejaculation: definition, serotonergic neurotransmission and drug treatment. World Journal of Urology 23, 102-108.

Waldinger, M.D., Schweitzer, D.H., 2005. Retarded ejaculation in men: an overview of psychological and neurobiological insights. World Journal of Urology 23, 76-81.

Waldinger, M.D., Berendsen, H.H., Blok, B.F., Olivier, B., Holstege, G., 1998a. Premature ejaculation and serotonergic antidepressants-induced delayed ejaculation: the involvement of the serotonergic system. Behavioural Brain Research 92, 111-118.

Waldinger, M.D., Hengeveld, M.W., Zwinderman, A.H., Olivier, B., 1998b. Effect of SSRI antidepressants on ejaculation: a double-blind, randomized, placebo-controlled study with fluoxetine, fluvoxamine, paroxetine, and sertraline. Journal of Clinical Psychopharmacology 18, 274-281.

Waldinger, M.D., Zwinderman, A.H., Olivier, B., 2001. SSRIs and ejaculation: a double-blind, randomized, fixed-dose study with paroxetine and citalopram. Journal of Clinical Psychopharmacology 21, 556-560.

Waldinger, M.D., van de Plas, A., Pattij, T., van Oorschot, R., Coolen, L.M., Veening, J.G., Olivier, B., 2002. The selective serotonin reuptake inhibitors fluvoxamine and paroxetine differ in sexual inhibitory effects after chronic treatment. Psychopharmacology (Berlin) 160, 283-289.

Waldinger, M.D., Zwinderman, A.H., Schweitzer, D.H., Olivier, B., 2004. Relevance of methodological design for the interpretation of efficacy of drug treatment of premature ejaculation: a systematic review and meta-analysis. International Journal of Impotence Research 16, 369-381. 
Waldinger, M.D., Quinn, P., Dilleen, M., Mundayat, R., Schweitzer, D.H., Boolell, M., 2005a. A multinational population survey of Intravaginal Ejaculation Latency Time. Journal of Sex and Medicicne 2, 492-497.

Waldinger, M.D., Zwinderman, A.H., Olivier, B., Schweitzer, D.H., 2005b. Proposal for a definition of lifelong premature ejaculation based on epidemiological stopwatch data. Journal of Sex and Medicicne 2, 498-507.

Watson, N.V., Gorzalka, B.B., 1991. DOI-induced inhibition of copulatory behavior in male rats: reversal by 5 -HT2 antagonists. Pharmacology Biochemistry and Behavior 39, 605-612.

Wegener, G., Bandpey, Z., Heiberg, I.L., Mork, A., Rosenberg, R., 2003. Increased extracellular serotonin level in rat hippocampus induced by chronic citalopram is augmented by subchronic lithium: neurochemical and behavioural studies in the rat. Psychopharmacology (Berlin) 166, 188-194.

Wright, D.E., Seroogy, K.B., Lundgren, K.H., Davis, B.M., Jennes, L., 1995. Comparative localization of serotonin $1 \mathrm{~A}, 1 \mathrm{C}$, and 2 receptor subtype mRNAs in rat brain. Journal of Comparative Neurology 351, 357-373.

Xu, C., Yaici, E.D., Conrath, M., Blanchard, P., Leclerc, P., Benoit, G., Verge, D., Giuliano, F., 2005. Galanin and neurokinin-1 receptor immunoreactivity spinal neurons controlling the prostate and the bulbospongiosus muscle identified by transsynaptic labeling in the rat. Neuroscience 134, 1325-1341.

Yamanouchi, K., Kakeyama, M., 1992. Effect of medullary raphe lesions on sexual behavior in male rats with or without treatments of p-chlorophenylalanine. Physiology \& Behavior 51, 575-579.

Yells, D.P., Hendricks, S.E., Prendergast, M.A., 1992. Lesions of the nucleus paragigantocellularis: effects on mating behavior in male rats. Brain Research 596, 73-79.
Yells, D.P., Prendergast, M.A., Hendricks, S.E., Nakamura, M., 1994. Fluoxetine-induced inhibition of male rat copulatory behavior: modification by lesions of the nucleus paragigantocellularis. Pharmacology Biochemistry and Behavior 49, 121-127.

Yonezawa, A., Watanabe, C., Ando, R., Furuta, S., Sakurada, S., Yoshimura, H., Iwanaga, T., Kimura, Y., 2000. Characterization of $p$-chloroamphetamine-induced penile erection and ejaculation in anesthetized rats. Life Sciences 67, 3031-3039.

Yonezawa, A., Ando, R., Imai, M., Watanabe, C., Furuta, S., Kutsuwa, M., Kimura, Y., Sakurada, S., 2004. Differential effects of yohimbine, naloxone and 8-OH-DPAT on ejaculatory response in male dogs. Methods and Findings in Experimental and Clinical Pharmacology 26, $47-51$.

Yoshitake, T., Reenila, I.I., Ogren, S.O., Hokfelt, T., Kehr, J., 2003. Galanin attenuates basal and antidepressant drug-induced increase of extracellular serotonin and noradrenaline levels in the rat hippocampus. Neuroscience Letters 339, 239-242.

Zhang, W., Perry, K.W., Wong, D.T., Potts, B.D., Bao, J., Tollefson, G.D., Bymaster, F.P., 2000. Synergistic effects of olanzapine and other antipsychotic agents in combination with fluoxetine on norepinephrine and dopamine release in rat prefrontal cortex. Neuropsychopharmacology 23, 250-262.

Zhang, Y., Gray, T.S., D’Souza, D.N., Carrasco, G.A., Damjanoska, K.J., Dudas, B., Garcia, F., Zainelli, G.M., Sullivan Hanley, N.R., Battaglia, G., Muma, N.A., Van De Kar, L.D., 2004. Desensitization of $5-\mathrm{HT}_{1 \mathrm{~A}}$ receptors by $5-\mathrm{HT} 2 \mathrm{~A}$ receptors in neuroendocrine neurons in vivo. Journal of Pharmacology and Experimental Therapeutics 310, $59-66$. 